\title{
Synthesis and diverse biological activity profile of triethyl- ammonium isatin-3-hydrazones
}

\author{
Andrei Bogdanov* ${ }^{1}$, Olga Tsivileva* ${ }^{2}$, Alexandra Voloshina ${ }^{1}$, Anna Lyubina $^{1}$, \\ Syumbelya Amerhanova ${ }^{1}$, Ekaterina Burtceva ${ }^{1}$, Sergey Bukharov ${ }^{3}$, Alexander \\ Samorodov ${ }^{4}$ and Valentin Pavlov ${ }^{4}$ \\ ${ }^{1}$ Arbuzov Institute of Organic and Physical Chemistry, FRC Kazan Scientific Center of RAS, Kazan, 420088, Russian \\ Federation \\ ${ }^{2}$ Institute of Biochemistry and Physiology of Plants and Microorganisms, Saratov Scientific Centre of the Russian \\ Academy of Sciences, Saratov 410049, Russian Federation \\ ${ }^{3}$ Kazan National Research Technological University, Kazan 420015, Russian Federation \\ ${ }^{4}$ Bashkir State Medical University, Ufa 450000, Russian Federation
}

*Corresponding Authors: Andrei Bogdanov e-mail: abogdanov@inbox.ru; Tel.: +7-962-562-44-18; Olga Tsivileva email: tsivileva@ibppm.ru; Tel.: +7-960-346-25-02

Received: November 15, 2021; Revised: January 07, 2022; Published: January 12, 2022

\begin{abstract}
A series of biorelevant triethylammonium isatin hydrazones containing various substituents in the aromatic fragment have been synthesized. Their structure and composition were confirmed by NMR- and IR-spectroscopies, mass-spectrometry and elemental analysis. It was found that some representatives show activity against Staphylococcus aureus and Bacillus cereus higher or the level of norfloxacin, including methicillin-resistant Staphylococcus aureus strains. The study also showed low hemo- and cytotoxicity (Chang Liver) and high antiaggregatory and anticoagulant activity of these compounds. The high potential of new ammonium isatin-3-acylhydrazones in the search for antimicrobial activity against phytopathogens of bacterial and fungal nature has been shown for the first time.
\end{abstract}

C 2021 by the authors. This article is an open-access article distributed under the terms and conditions of the Creative Commons Attribution license (http://creativecommons.org/licenses/by/4.0/).

\section{Keywords}

isatin; hemostasis; phytopathogens, antibacterial and antifungal activities

\section{Introduction}

As a representative of the class of privileged structures, isatin and its derivatives are widely used in medicinal chemistry [1,2]. The progressing number of works on synthetic procedures [3] and the studies of this heterocycle push researchers in this area to publish generalized data on one or another type of biological activity [4-7]. It is due to the manifestation of isatin and its derivatives of a wide spectrum of activity, such as anti-cancer [8-10], anti-tubercular [11,12], antibacterial [13], anti-COVID [14,15], fungicidal [16,17], etc (Fig. 1). 

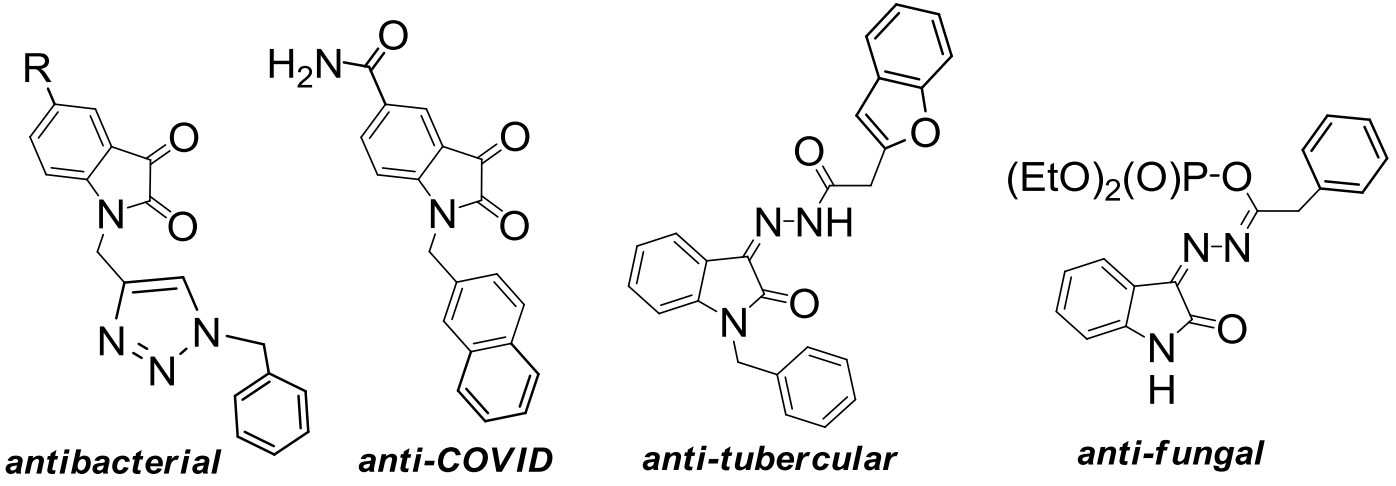

Figure 1. Biologically active isatins and isatin-3-acylhydrazones

One of the modern trends in the design and targeted synthesis of bioactive isatin derivatives is the concept of molecular hybridization [18-21]. In this regard, the combination of a pharmacophore fragment and a quaternized nitrogen atom in one molecule seems to be promising in terms of the search for effective and non-toxic biorelevant drugs $[22,23]$. In recent years, our research group has been working in this direction, namely in the synthesis and study of the antimicrobial activity of water-soluble isatin hydrazones containing a positively charged nitrogen atom (Fig. 2) [24-30]. Those studies showed the dependence of antimicrobial activity on many structural factors. Thus, in the series of trimethylammonium isatin acylhydrazones, sterically hindered analogs showed the best activity against some Gram-positive bacteria [24-26]. We also found that both an increase in the lipophilicity of the benzyl substituent [30] and the presence of an alkyl chain of medium length $\left(\mathrm{C}_{10}-\mathrm{C}_{12}\right)$ [27] in position 1 leads to an improvement in antimicrobial activity. It is important that all previously obtained compounds have low hemo- and cytotoxic effects.

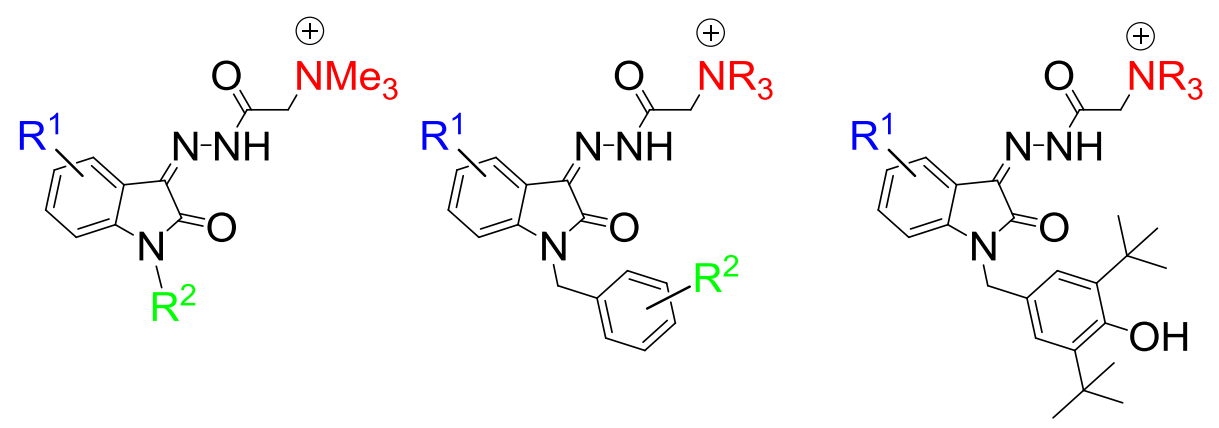

Figure 2. Antimicrobial ammonium isatin-3-acylhydrazones

\section{Experimental}

\section{Materials and methods}

Starting isatins 1a-g were synthesized accordingly to our previously reported procedure [24]. IR spectra were measured with a Bruker Vector-22 instrument for the samples in $\mathrm{KBr}$ pellets. ${ }^{1} \mathrm{H}$ and ${ }^{13} \mathrm{C}$ NMR spectra were recorded on a Bruker Avance-400 or Bruker Avance-600 Bruker spectrometers at 400, 600 and 100.6, $150 \mathrm{MHz}$, respectively. Chemical shifts were reported in ppm relative to residual signals of deuterated solvents. $\mathrm{CDCl}_{3}$, DMSO- $\mathrm{d}_{6}$ or a mixture of $C D \mathrm{Cl}_{3} / D M S O-\mathrm{d}_{6}$ were used as the NMR solvents. MALDI mass spectra were recorded on an UltraFlex III TOF/TOF mass spectrometer in linear mode with a recording of positive ions, metal target, and p-nitroaniline matrix. Elemental analysis was performed on a Euro Vector 2000 CHNS-3 instrument; halogen content was determined by pyrolysis in the oxygen stream. Melting points were determined using an SMP10 Stuart instrument and uncorrected. 
$\mathrm{N}, \mathrm{N}, \mathrm{N}$-Triethyl-2-hydrazinyl-2-oxoethanammonium bromide (1). White crystalline powder. Yield: $73 \%$; m.p. $135^{\circ} \mathrm{C}$. IR (KBr, cm${ }^{-1}$ ): $3298(\mathrm{~N}-\mathrm{H}), 3191(\mathrm{~N}-\mathrm{H}), 3010(\mathrm{C}-\mathrm{H}), 2946(\mathrm{C}-\mathrm{H}), 1680$ (C=O), 1646 (C=O), 1530 (N-H); 1449 (C-N). ${ }^{1} \mathrm{H}$ NMR (600 MHz, DMSO-d $\left.6, \delta, p p m\right): 1.23$ t (9H, $\left.\mathrm{CH}_{3}, \mathrm{Et}, \mathrm{J} 7.2 \mathrm{~Hz}\right) ; 3.43 \mathrm{q}\left(6 \mathrm{H}, \mathrm{CH}_{2}, \mathrm{Et}, \mathrm{J}\right.$ $7.2 \mathrm{~Hz}) ; 3.98 \mathrm{~s}\left(2 \mathrm{H}, \mathrm{CH}_{2} \mathrm{CO}\right) ; 4.51$ br. s [2H, NH $\left.\mathrm{N}_{2}\right] 9.89 \mathrm{~s}(1 \mathrm{H}, \mathrm{NH}) .{ }^{13} \mathrm{C}$ NMR $\left(150 \mathrm{MHz}, \mathrm{DMSO}-\mathrm{d}_{6}, \delta, \mathrm{ppm}\right)$ : 160.90 (C=O); $55.19\left(\mathrm{CH}_{2}\right) ; 54.24\left(\mathrm{CH}_{2}\right) ; 8.45\left(\mathrm{CH}_{3}\right)$. MS (MALDI): 213 [M+K-Br] $]^{+}$. Found, \%: C, 37.67; H, 7.84; $\mathrm{Br}, 31.32 ; \mathrm{N}, 16.46 . \mathrm{C}_{8} \mathrm{H}_{20} \mathrm{BrN}_{3} \mathrm{O}$. Calculated, \%: C, 37.80; $\mathrm{H}, 7.93 ; \mathrm{Br}, 31.44 ; \mathrm{N}, 16.53$.

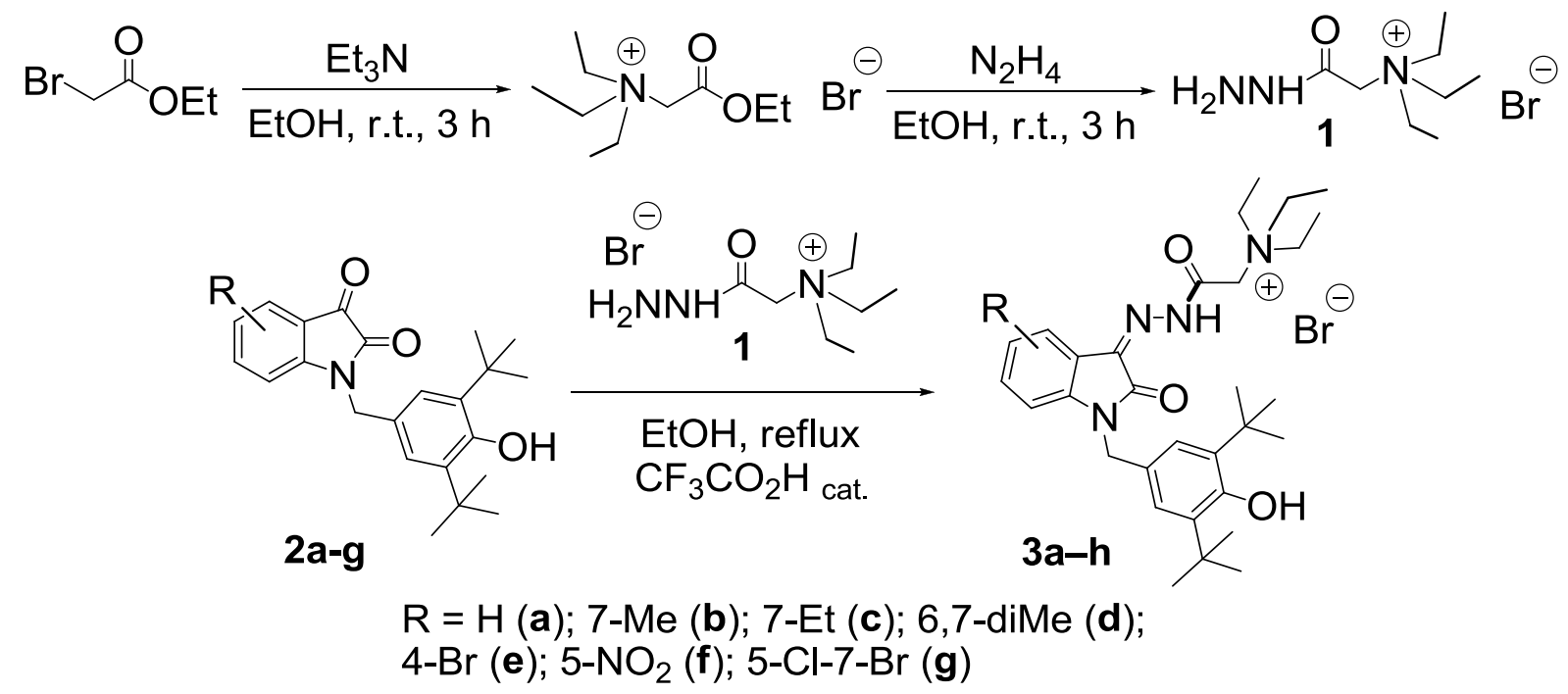

Scheme 1. Synthetic route to the ammonium hydrazones 3a-g

General procedure for the synthesis of compounds 3a-g.

A mixture of substituted isatin 1a-g $(1 \mathrm{mmol})$ and hydrazide $2(1 \mathrm{mmol})$ was magnetically stirred in absolute ethanol $(7 \mathrm{~mL})$ for $10 \mathrm{~min}$, followed by the addition of trifluoroacetic acid ( $20 \mathrm{~mol} \%$ ). Then the reaction mixture was heated at reflux for $3 \mathrm{~h}$. After cooling the solution to room temperature, the solvent was rotary evaporated. The formed precipitate was washed with anhydrous diethyl ether, filtered off and dried in vacuum $(12 \mathrm{mmHg})$.

2-(2-(1-(3,5-Di-tert-butyl-4-hydroxybenzyl)-2-oxoindolin-3-ylidene)hydrazinyl)-N,N,N-triethyl-2oxoethanammonium bromide (3a).

Yellow powder. Yield: $92 \%$; m.p. $212{ }^{\circ} \mathrm{C}$. IR $\left(\mathrm{KBr}, \mathrm{cm}^{-1}\right): 3631(\mathrm{O}-\mathrm{H}), 3232(\mathrm{~N}-\mathrm{H}), 2950(\mathrm{C}-\mathrm{H}), 1713$ (C=O), $1673(\mathrm{C}=\mathrm{O}), 1617(\mathrm{C}=\mathrm{C}), 1469(\mathrm{C}=\mathrm{N}) .{ }^{1} \mathrm{H}$ NMR $\left(600 \mathrm{MHz}, \mathrm{CDCl}_{3}, \delta, \mathrm{ppm}\right): 1.36 \mathrm{~s}\left(18 \mathrm{H}, \mathrm{CH}_{3}, \mathrm{t}-\mathrm{Bu}\right) ; 1.44 \mathrm{t}(9 \mathrm{H}$, $\mathrm{CH}_{3}$, Et, J $\left.6.9 \mathrm{~Hz}\right) ; 3.88 \mathrm{q}\left(6 \mathrm{H}, \mathrm{CH}_{2}\right.$, Et, J $\left.7.0 \mathrm{~Hz}\right) ; 4.75 \mathrm{~s}\left[2 \mathrm{H}, \mathrm{NCH}_{2}\right] ; 5.02 \mathrm{~s}\left(2 \mathrm{H}, \mathrm{CH}_{2} \mathrm{CO}\right) ; 5.17 \mathrm{~s}(1 \mathrm{H}, \mathrm{OH}) ; 6.84 \mathrm{~d}$ $(1 \mathrm{H}, 7-\mathrm{H}, \mathrm{Ar}, \mathrm{J} 7.8 \mathrm{~Hz}) ; 8.02-8.03 \mathrm{~m}(3 \mathrm{H}, 5-\mathrm{H}, \mathrm{Ar}, 2 \mathrm{H}$, benzyl); $7.29 \mathrm{dd}(1 \mathrm{H}, 6-\mathrm{H}, \mathrm{Ar}, \mathrm{J} 7.6 \mathrm{~Hz}, \mathrm{~J} 7.6 \mathrm{~Hz}) ; 8.03 \mathrm{~d}$ $(1 \mathrm{H}, 4-\mathrm{H}, \mathrm{Ar}, \mathrm{J} 7.2 \mathrm{~Hz}) ; 12.83 \mathrm{~s}(1 \mathrm{H}, \mathrm{NH}) .{ }^{13} \mathrm{C} \mathrm{NMR}\left(150 \mathrm{MHz}, \mathrm{CDCl}_{3}, \delta, \mathrm{ppm}\right): 165.51$ (C=O); 160.90 (C=O); 153.50 (C-OH); 143.49; 136.51; 136.38; $132.07(\mathrm{CH}) ; 125.25 ; 124.49(\mathrm{CH}) ; 123.83(\mathrm{CH}) ; 123.30(\mathrm{CH}) ; 118.77$; $109.77(\mathrm{CH}) ; 55.19\left(\mathrm{CH}_{2}\right) ; 54.24\left(\mathrm{CH}_{2}\right) ; 43.84\left(\mathrm{CH}_{2}\right) ; 34.15$ (C, t-Bu); $30.06\left(\mathrm{CH}_{3}, \mathrm{t}-\mathrm{Bu}\right) ; 8.45\left(\mathrm{CH}_{3}\right)$. MS (MALDI): $521[\mathrm{M}-\mathrm{Br}]^{+}$. Found, \%: C, 61.79; $\mathrm{H}, 7.45 ; \mathrm{Br}, 13.16 ; \mathrm{N}, 9.25 . \mathrm{C}_{31} \mathrm{H}_{45} \mathrm{BrN}_{4} \mathrm{O}_{3}$. Calculated, \%: C, 61.89; H, 7.54; $\mathrm{Br}, 13.28 ; \mathrm{N}, 9.31$.

2-(2-(1-(3,5-Di-tert-butyl-4-hydroxybenzyl)-7-methyl-2-oxoindolin-3-ylidene)hydrazinyl)-N,N,N-triethyl-2oxoethanammonium bromide $(\mathbf{3 b})$.

Yellow powder. Yield: $97 \%$; m.p. $154{ }^{\circ} \mathrm{C} . \mathrm{IR}\left(\mathrm{KBr}, \mathrm{cm}^{-1}\right)$ : $3634(\mathrm{O}-\mathrm{H}), 3204(\mathrm{~N}-\mathrm{H}), 2959(\mathrm{C}-\mathrm{H}), 1714$ $(\mathrm{C}=0), 1683(\mathrm{C}=\mathrm{O}), 1606(\mathrm{C}=\mathrm{C}), 1446(\mathrm{C}=\mathrm{N}) .{ }^{1} \mathrm{H}$ NMR $\left(400 \mathrm{MHz}, \mathrm{CDCl}_{3}, \delta, \mathrm{ppm}\right): 1.36 \mathrm{~s}\left(18 \mathrm{H}, \mathrm{CH}_{3}, \mathrm{t}-\mathrm{Bu}\right) ; 1.48 \mathrm{t}$

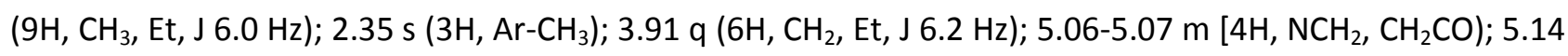
br. $\mathrm{s}(1 \mathrm{H}, \mathrm{OH}) ; 6.97-7.00 \mathrm{~m}(3 \mathrm{H}, 6-\mathrm{H}, \mathrm{Ar}, 2 \mathrm{H}$, benzyl); 7.08-7.11 m (1H, 5-H, Ar); $8.03 \mathrm{~d}(1 \mathrm{H}, 4-\mathrm{H}, \mathrm{Ar}, \mathrm{J} 7.0 \mathrm{~Hz})$; 
$12.91 \mathrm{~s}(1 \mathrm{H}, \mathrm{NH})$. MS (MALDI): $535[\mathrm{M}-\mathrm{Br}]^{+}$. Found, \%: C, 62.30; $\mathrm{H}, 7.56 ; \mathrm{Br}, 12.81 ; \mathrm{N}, 9.01 . \mathrm{C}_{32} \mathrm{H}_{47} \mathrm{BrN}_{4} \mathrm{O}_{3}$. Calculated, \%: C, 62.43; H, 7.69; $\mathrm{Br}, 12.98 ; \mathrm{N}, 9.10$.

2-(2-(1-(3,5-Di-tert-butyl-4-hydroxybenzyl)-7-ethyl-2-oxoindolin-3-ylidene)hydrazinyl)-N,N,N-triethyl-2oxoethanammonium bromide (3c).

Yellow powder. Yield: 89 \%; m.p. $163{ }^{\circ} \mathrm{C}$. IR $\left(\mathrm{KBr}, \mathrm{cm}^{-1}\right): 3609(\mathrm{O}-\mathrm{H}), 3392(\mathrm{~N}-\mathrm{H}), 3208(\mathrm{~N}-\mathrm{H}), 2957(\mathrm{C}-\mathrm{H})$, $1682(\mathrm{C}=\mathrm{O}), 1606(\mathrm{C}=\mathrm{C}), 1460(\mathrm{C}=\mathrm{N}), 1436(\mathrm{C}=\mathrm{N}) .{ }^{1} \mathrm{H}$ NMR $\left(600 \mathrm{MHz}, \mathrm{DMSO}-\mathrm{d}_{6}, \delta, \mathrm{ppm}\right): 0.93 \mathrm{t}\left(3 \mathrm{H}, \mathrm{CH}_{3}, \mathrm{Et}, \mathrm{J}\right.$ $7.3 \mathrm{~Hz}) ; 1.27-1.29 \mathrm{~m}\left(27 \mathrm{H}, \mathrm{CH}_{3}, \mathrm{t}-\mathrm{Bu}, \mathrm{CH}_{3}, \mathrm{Et}\right) ; 2.63 \mathrm{q}\left(2 \mathrm{H}, \mathrm{CH}_{2}, \mathrm{Et}, \mathrm{J} 7.3 \mathrm{~Hz}\right) ; 3.57-3.62 \mathrm{~m}\left(6 \mathrm{H}, \mathrm{CH}_{2}, \mathrm{Et}\right) ; 4.58 \mathrm{~s}$ $(1 \mathrm{H}, \mathrm{OH}) ; 4.80 \mathrm{~s}\left(2 \mathrm{H}, \mathrm{CH}_{2} \mathrm{CO}\right) ; 5.06 \mathrm{~s}\left[2 \mathrm{H}, \mathrm{NCH}_{2}\right] ; 6.93 \mathrm{~s}(2 \mathrm{H}, 2 \mathrm{H}$, benzyl); 7.13-7.17 m (1H, 5-H, Ar); $7.27 \mathrm{~d}$ $(1 \mathrm{H}, 7-\mathrm{H}, \mathrm{Ar}, \mathrm{J} 7.1 \mathrm{~Hz}) ; 7.65-7.69 \mathrm{~m}(1 \mathrm{H}, 4-\mathrm{H}, \mathrm{Ar}) ; 12.64 \mathrm{~s}(1 \mathrm{H}, \mathrm{NH}) .{ }^{13} \mathrm{C} N M R\left(150 \mathrm{MHz}, \mathrm{DMSO}-\mathrm{d}_{6}, \delta, \mathrm{ppm}\right)$ : $166.21(\mathrm{C}=\mathrm{O}) ; 161.45(\mathrm{C}=\mathrm{O}) ; 152.96(\mathrm{C}-\mathrm{OH}) ; 140.48 ; 139.70 ; 134.41(\mathrm{CH}) ; 127.73 ; 127.19 ; 123.63(\mathrm{CH})$; $122.01(2 \mathrm{CH}) ; 119.64 ; 118.99 ; 54.18\left(\mathrm{CH}_{2}\right) ; 53.15\left(\mathrm{CH}_{2}\right) ; 44.63\left(\mathrm{CH}_{2}\right) ; 34.41(\mathrm{C}, \mathrm{t}-\mathrm{Bu}) ; 30.15\left(\mathrm{CH}_{3}, \mathrm{t}-\mathrm{Bu}\right) ; 23.35$ $\left(\mathrm{CH}_{2}\right) ; 15.56\left(\mathrm{CH}_{3}\right) ; 7.49\left(\mathrm{CH}_{3}\right)$. MS (MALDI): $549[\mathrm{M}-\mathrm{Br}]^{+}$. Found, \%: C, 62.80; H, 7.73; Br, 12.59; N, 8.78. $\mathrm{C}_{33} \mathrm{H}_{49} \mathrm{BrN}_{4} \mathrm{O}_{3}$. Calculated, \%: C, 62.95; $\mathrm{H}, 7.84 ; \mathrm{Br}, 12.69 ; \mathrm{N}, 8.90$.

2-(2-(1-(3,5-Di-tert-butyl-4-hydroxybenzyl)-6,7-dimethyl-2-oxoindolin-3-ylidene)hydrazinyl)-N,N,N-triethyl2-oxoethanammonium bromide (3d).

Yellow powder. Yield: 94 \%; m.p. $187^{\circ} \mathrm{C}$. IR $\left(\mathrm{KBr}, \mathrm{cm}^{-1}\right)$ : $3415(\mathrm{O}-\mathrm{H}), 3199(\mathrm{~N}-\mathrm{H}), 2952$ (C-H), 1707 (C=O), $1678(\mathrm{C}=\mathrm{O}), 1611(\mathrm{C}=\mathrm{C}), 1463(\mathrm{C}=\mathrm{N}), 1435(\mathrm{C}=\mathrm{N}) .{ }^{1} \mathrm{H}$ NMR $\left(600 \mathrm{MHz}, \mathrm{CDCl}_{3}, \delta, \mathrm{ppm}\right): 1.34 \mathrm{~s}\left(18 \mathrm{H}, \mathrm{CH}_{3}, \mathrm{t}-\mathrm{Bu}\right)$; $1.46 \mathrm{t}\left(9 \mathrm{H}, \mathrm{CH}_{3}, \mathrm{Et}, \mathrm{J} 7.3 \mathrm{~Hz}\right) ; 2.18 \mathrm{~s}\left(3 \mathrm{H}, \mathrm{Ar}-\mathrm{CH}_{3}\right) ; 2.24 \mathrm{~s}\left(3 \mathrm{H}, \mathrm{Ar}-\mathrm{CH}_{3}\right) ; 3.89 \mathrm{q}\left(6 \mathrm{H}, \mathrm{CH}_{2}, \mathrm{Et}, \mathrm{J} 7.3 \mathrm{~Hz}\right) ; 4.97 \mathrm{~s}[2 \mathrm{H}$, $\left.\mathrm{CH}_{2} \mathrm{CO}\right) ; 5.05 \mathrm{~s}\left[2 \mathrm{H}, \mathrm{NCH}_{2}\right) ; 5.13$ br. s $(1 \mathrm{H}, \mathrm{OH}) ; 6.93-6.95 \mathrm{~m}(3 \mathrm{H}, 5-\mathrm{H}, \mathrm{Ar}, 2 \mathrm{H}$, benzyl); $7.77 \mathrm{~d}(1 \mathrm{H}, 4-\mathrm{H}, \mathrm{Ar}, \mathrm{J}$ $7.1 \mathrm{~Hz}) ; 12.83 \mathrm{~s}(1 \mathrm{H}, \mathrm{NH}) .{ }^{13} \mathrm{C} \mathrm{NMR}\left(150 \mathrm{MHz}, \mathrm{CDCl}_{3}, \delta, \mathrm{ppm}\right): 165.31$ (C=O); 162.66 (C=O); $153.10(\mathrm{C}-\mathrm{OH})$; $143.55 ; 142.00 ; 136.57 ; 136.41 ; 126.67 ; 125.90(\mathrm{CH}) ; 122.61(\mathrm{CH}) ; 120.54 ; 120.15 ; 117.67 ; 55.26\left(\mathrm{CH}_{2}\right)$; $54.22\left(\mathrm{CH}_{2}\right) ; 45.53\left(\mathrm{CH}_{2}\right) ; 34.23(\mathrm{C}, \mathrm{t}-\mathrm{Bu}) ; 30.12\left(\mathrm{CH}_{3}, \mathrm{t}-\mathrm{Bu}\right) ; 21.36\left(\mathrm{CH}_{3}\right) ; 13.85\left(\mathrm{CH}_{3}\right) ; 8.50\left(\mathrm{CH}_{3}\right)$. MS (MALDI): $535[\mathrm{M}-\mathrm{Br}]^{+}$. Found, \%: $\mathrm{C}, 62.35 ; \mathrm{H}, 7.50 ; \mathrm{Br}, 12.83 ; \mathrm{N}, 8.99 . \mathrm{C}_{32} \mathrm{H}_{47} \mathrm{BrN}_{4} \mathrm{O}_{3}$. Calculated, \%: $\mathrm{C}, 62.43 ; \mathrm{H}, 7.69$; $\mathrm{Br}, 12.98 ; \mathrm{N}, 9.10$.

\section{2-(2-(1-(3,5-Di-tert-butyl-4-hydroxybenzyl)-4-bromo-2-oxoindolin-3-ylidene)hydrazinyl)-N,N,N-triethyl-2-} oxoethanammonium bromide (3e).

Yellow powder. Yield: 89 \%; m.p. $194^{\circ} \mathrm{C} . \mathrm{IR}\left(\mathrm{KBr}, \mathrm{cm}^{-1}\right): 3592(\mathrm{O}-\mathrm{H}), 3367(\mathrm{~N}-\mathrm{H}), 3199(\mathrm{~N}-\mathrm{H}), 2952(\mathrm{C}-\mathrm{H})$, $1686(\mathrm{C}=\mathrm{O}), 1607$ (C=C), $1447(\mathrm{C}=\mathrm{N}), 1433(\mathrm{C}=\mathrm{N}) .{ }^{1} \mathrm{H}$ NMR (400 MHz, CDCl $\left., \delta, \mathrm{ppm}\right): 1.37 \mathrm{~s}\left(18 \mathrm{H}, \mathrm{CH}_{3}, \mathrm{t}-\mathrm{Bu}\right)$; $1.48 \mathrm{t}\left(9 \mathrm{H}, \mathrm{CH}_{3}\right.$, Et, J $\left.6.9 \mathrm{~Hz}\right) ; 3.90 \mathrm{q}\left(6 \mathrm{H}, \mathrm{CH}_{2}\right.$, Et, J $\left.7.0 \mathrm{~Hz}\right) ; 4.78 \mathrm{~s}\left[2 \mathrm{H}, \mathrm{NCH}_{2}\right] ; 4.87 \mathrm{~s}\left(2 \mathrm{H}, \mathrm{CH}_{2} \mathrm{CO}\right) ; 5.22 \mathrm{~s}(1 \mathrm{H}$, $\mathrm{OH}) ; 6.88 \mathrm{~d}(1 \mathrm{H}, 7-\mathrm{H}, \mathrm{Ar}, \mathrm{J} 7.8 \mathrm{~Hz}) ; 7.09 \mathrm{~s}(2 \mathrm{H}, 2 \mathrm{H}$, benzyl); $7.18 \mathrm{dd}(1 \mathrm{H}, 6-\mathrm{H}, \mathrm{Ar}, \mathrm{J} 7.8 \mathrm{~Hz}, \mathrm{~J} 7.8 \mathrm{~Hz}) ; 7.26 \mathrm{~d}(1 \mathrm{H}$, $5-\mathrm{H}, \mathrm{Ar}, \mathrm{J} 7.8 \mathrm{~Hz}) ; 12.93 \mathrm{~s}(1 \mathrm{H}, \mathrm{NH}) .{ }^{13} \mathrm{C} \mathrm{NMR}\left(100.6 \mathrm{MHz}, \mathrm{CDCl}_{3}, \delta, \mathrm{ppm}\right): 165.37$ (C=O); 160.07 (C=O); 153.42 (C-OH); 144.64; 136.33; 134.60; $132.27(\mathrm{CH}) ; 128.00(\mathrm{C}-\mathrm{H}) ; 124.67 ; 124.34(\mathrm{CH}) ; 117.79 ; 117.09 ; 108.87$ $(\mathrm{CH}) ; 65.40\left(\mathrm{CH}_{2}\right) ; 55.64\left(\mathrm{CH}_{2}\right) ; 43.87\left(\mathrm{CH}_{2}\right) ; 33.94$ (C, t-Bu); $29.87\left(\mathrm{CH}_{3}, \mathrm{t}-\mathrm{Bu}\right) ; 8.39\left(\mathrm{CH}_{3}\right)$. MS (MALDI): 601 $[\mathrm{M}-\mathrm{Br}]^{+}$. Found, \%: $\mathrm{C}, 54.60 ; \mathrm{H}, 6.40 ; \mathrm{Br}, 23.33 ; \mathrm{N}, 8.11 . \mathrm{C}_{31} \mathrm{H}_{44} \mathrm{Br}_{2} \mathrm{~N}_{4} \mathrm{O}_{3}$. Calculated, \%: $\mathrm{C}, 54.71 ; \mathrm{H}, 6.52 ; \mathrm{Br}$, 23.48; N, 8.23.

\section{2-(2-(1-(3,5-Di-tert-butyl-4-hydroxybenzyl)-5-nitro-2-oxoindolin-3-ylidene)hydrazinyl)-N,N,N-triethyl-2-} oxoethanammonium bromide (3f).

Yellow powder. Yield: 89 \%; m.p. $176^{\circ} \mathrm{C}$. IR $\left(\mathrm{KBr}, \mathrm{cm}^{-1}\right): 3621(\mathrm{O}-\mathrm{H}), 3392(\mathrm{~N}-\mathrm{H}), 3215(\mathrm{~N}-\mathrm{H}), 2954(\mathrm{C}-\mathrm{H})$, $1693(\mathrm{C}=\mathrm{O}), 1617(\mathrm{C}=\mathrm{C}), 1523(\mathrm{~N}=\mathrm{O}), 1486(\mathrm{C}=\mathrm{N}), 1434(\mathrm{C}=\mathrm{N}) .{ }^{1} \mathrm{H} \mathrm{NMR}\left(400 \mathrm{MHz}, \mathrm{CDCl}_{3}, \delta, \mathrm{ppm}\right): 1.38 \mathrm{~s}$ $\left(18 \mathrm{H}, \mathrm{CH}_{3}, \mathrm{t}-\mathrm{Bu}\right) ; 1.49 \mathrm{t}\left(9 \mathrm{H}, \mathrm{CH}_{3}, \mathrm{Et}, \mathrm{J} 6.3 \mathrm{~Hz}\right) ; 3.86-3.90 \mathrm{~m}\left(6 \mathrm{H}, \mathrm{CH}_{2}, \mathrm{Et}\right) ; 4.84 \mathrm{~s}\left[2 \mathrm{H}, \mathrm{NCH}_{2}\right] ; 5.22 \mathrm{~s}(1 \mathrm{H}, \mathrm{OH})$; $5.28 \mathrm{~s}\left(2 \mathrm{H}, \mathrm{CH}_{2} \mathrm{CO}\right) ; 6.94 \mathrm{~d}(1 \mathrm{H}, 7-\mathrm{H}, \mathrm{Ar}, \mathrm{J} 8.5 \mathrm{~Hz}) ; 7.09 \mathrm{~s}(2 \mathrm{H}, 2 \mathrm{H}$, benzyl); $8.18 \mathrm{~d}(1 \mathrm{H}, 6-\mathrm{H}, \mathrm{Ar}, \mathrm{J} 8.5 \mathrm{~Hz}) ; 8.90$ br. s $(1 \mathrm{H}, 4-\mathrm{H}, \mathrm{Ar}) ; 12.67 \mathrm{~s}(1 \mathrm{H}, \mathrm{NH}) .{ }^{13} \mathrm{C} N M R\left(150 \mathrm{MHz}, \mathrm{DMSO}-\mathrm{d}_{6}, \delta, \mathrm{ppm}\right): 167.15$ (C=0); 161.62 (C=O); 
153.52 (C-OH); $148.20 ; 143.26 ; 139.51 ; 127.92(\mathrm{C}-\mathrm{H}) ; 125.94 ; 124.28(2 \mathrm{CH}) ; 119.59 ; 116.21 ; 110.96(\mathrm{CH})$; $54.09\left(\mathrm{CH}_{2}\right) ; 53.90\left(\mathrm{CH}_{2}\right) ; 43.54\left(\mathrm{CH}_{2}\right) ; 34.41(\mathrm{C}, \mathrm{t}-\mathrm{Bu}) ; 30.20\left(\mathrm{CH}_{3}, \mathrm{t}-\mathrm{Bu}\right) ; 7.49\left(\mathrm{CH}_{3}\right) . \mathrm{MS}$ (MALDI): 566 [M-Br] ${ }^{+}$. Found, \%: $\mathrm{C}, 57.42 ; \mathrm{H}, 6.70 ; \mathrm{Br}, 12.21 ; \mathrm{N}, 10.70 . \mathrm{C}_{31} \mathrm{H}_{44} \mathrm{BrN}_{5} \mathrm{O}_{5}$. Calculated, \%: $\mathrm{C}, 57.58 ; \mathrm{H}, 6.86 ; \mathrm{Br}, 12.36 ; \mathrm{N}$, 10.83.

2-(2-(1-(3,5-Di-tert-butyl-4-hydroxybenzyl)-5-chloro-7-bromo-2-oxoindolin-3-ylidene)hydrazinyl)-N,N,Ntriethyl-2-oxoethanammonium bromide $(3 \mathrm{~g})$.

Yellow powder. Yield: 89 \%; m.p. $177^{\circ} \mathrm{C}$. IR $\left(\mathrm{KBr}, \mathrm{cm}^{-1}\right)$ : $3629(\mathrm{O}-\mathrm{H}), 3400(\mathrm{~N}-\mathrm{H}), 3209(\mathrm{~N}-\mathrm{H}), 2956(\mathrm{C}-\mathrm{H})$,

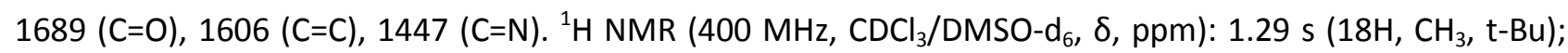
$1.33 \mathrm{t}\left(3 \mathrm{H}, \mathrm{CH}_{3}, \mathrm{Et}, \mathrm{J} 7.1 \mathrm{~Hz}\right) ; 3.66-3.70 \mathrm{~m}\left(6 \mathrm{H}, \mathrm{CH}_{2}, \mathrm{Et}\right) ; 4.87 \mathrm{~s}\left(2 \mathrm{H}, \mathrm{CH}_{2} \mathrm{CO}\right) ; 5.22 \mathrm{~s}\left[2 \mathrm{H}, \mathrm{NCH}_{2}\right] ; 7.04 \mathrm{~s}(2 \mathrm{H}, 2 \mathrm{H}$, benzyl); $7.51 \mathrm{~s}(1 \mathrm{H}, \mathrm{OH}) ; 7.68-7.69 \mathrm{~m}(1 \mathrm{H}, 6-\mathrm{H}, \mathrm{Ar}) ; 7.88 \mathrm{br}$. s $(1 \mathrm{H}, 4-\mathrm{H}, \mathrm{Ar}) ; 12.58 \mathrm{~s}(1 \mathrm{H}, \mathrm{NH}) .{ }^{13} \mathrm{C} \mathrm{NMR}(100.6$ $\mathrm{MHz}, \mathrm{CDCl}_{3} / \mathrm{DMSO}_{6}, \delta, \mathrm{ppm}$ ): 166.14 (C=O); 161.24 (C=O); 153.59 (C-OH); 139.41; 138.11; 136.48 (C-H); 129.29; 127.30; 126.76; 123.98 (C-H); 123.43; 121.22 (C-H); 103.72; $54.90\left(\mathrm{CH}_{2}\right) ; 54.13\left(\mathrm{CH}_{2}\right) ; 44.49\left(\mathrm{CH}_{2}\right)$; 34.60 (C, t-Bu); $30.39\left(\mathrm{CH}_{3}, \mathrm{t}-\mathrm{Bu}\right) ; 8.15\left(\mathrm{CH}_{3}\right) . \mathrm{MS}$ (MALDI): 635 [M-Br] ${ }^{+}$. Found, \%: C, 51.90; $\mathrm{H}, 5.91 ; \mathrm{Br}$, 22.23; $\mathrm{Cl}, 4.72 ; \mathrm{N}, 7.71 . \mathrm{C}_{31} \mathrm{H}_{43} \mathrm{Br}_{2} \mathrm{ClN}_{4} \mathrm{O}_{3}$. Calculated, \%: $\mathrm{C}, 52.08 ; \mathrm{H}, 6.06 ; \mathrm{Br}, 22.35 ; \mathrm{Cl}, 4.96 ; \mathrm{N}, 7.84$.

\section{Antimicrobial activity study}

The antimicrobial activity of the test compounds was determined by the serial dilution technique in Muller Hinton Broth 2 and in Sabouradu broth for fungi. The cultures used for testing included Grampositive bacteria: Staphylococcus aureus ATCC 6538P FDA 209P, Bacillus cereus ATCC 10702 NCTC 8035, Enterococcus faecalis ATCC 29212; Gram-negative bacteria: Escherichia coli ATCC 25922, Pseudomonas aeruginosa ATCC 9027, and fungi: Trichophyton mentagrophytes var. gypseum 1773, and Candida albicans ATCC 10231; methicillin-resistant strains of S. aureus (MRSA) was obtained from hospital patients with chronic tonsillitis in the Republican Clinical Hospital (Kazan, Russia). The bacterial load was $3.0 \times 10^{5} \mathrm{cfu} / \mathrm{ml}$. The fungi load was $2.0 \times 10^{3} \mathrm{cfu} / \mathrm{ml}$. The results were recorded every $24 \mathrm{~h}$ for 5-7 days. Cultures were incubated at $37{ }^{\circ} \mathrm{C}$. The experiment was repeated three times. The dilutions of the compounds were prepared immediately in nutrient media; $5 \%$ DMSO was added for better solubility and the test strains were not inhibited at this concentration. The minimum inhibitory concentration (MIC) was defined as the minimum concentration of a compound that inhibits the growth of the corresponding test microorganism. The growth of bacteria, as well as the absence of the growth due to the bacteriostatic action of compounds, were recorded. To determine minimal bactericidal concentration $(\mathrm{MBC})$, an aliquot of the bacterial culture was transferred onto Mueller-Hinton agar or Sabouradu agar in a 10-cm Petri dish and incubated for $24 \mathrm{~h}$ at $37{ }^{\circ} \mathrm{C}$. MBC was the minimal concentration at which bacterial colonies were not detected, indicating that the bacteria were killed with an efficiency of $>99.9 \%$ [31].

\section{Hemolytic activity}

Hemolytic activity of test compounds was estimated by comparing the optical density of a solution containing the test compound with that of blood at $100 \%$ hemolysis. The experiments were carried out as described earlier [32].

\section{Cytotoxicity assay}

Cytotoxic effects of the test compounds on human normal cells were estimated by means of the multifunctional Cytell Cell Imaging system (GE Health Care Life Science, Sweden) using the Cell Viability Bio App which precisely counts the number of cells and evaluates their viability from fluorescence intensity [32]. Two fluorescent dyes that selectively penetrate the cell membranes and fluoresce at different wavelengths were used in the experiments. DAPI is able to penetrate intact membranes of living cells and 
colors nuclei in blue and Propidium iodide dye penetrates only dead cells with damaged membranes, staining them in yellow. DAPI and propidium iodide were purchased from Sigma. $I \mathrm{C}_{50}$ was calculated using an online tool: MLA-“Quest Graph ${ }^{\mathrm{TM}}$ IC50 Calculator.” AAT Bioquest, Inc, 15 July, 2021, https://www.aatbio.com/tools/ic50-calculator. Chang liver cell line (Human liver cells) from N. F. Gamaleya Research Center of Epidemiology and Microbiology was used in the experiments. The cells were cultured in a standard Eagle's nutrient medium manufactured at the Chumakov Institute of Poliomyelitis and Virus Encephalitis (PanEco company) and supplemented with $10 \%$ fetal calf serum and $1 \%$ nonessential amino acids. The cells were plated into a 96-well plate (Nunc) at a concentration of $1 \times 10^{5}$ cells $/ \mathrm{mL}, 150 \mu \mathrm{L}$ of medium per well, and cultured in a $\mathrm{CO}_{2}$ incubator at $37{ }^{\circ} \mathrm{C}$. Twenty-four hours after seeding the cells into wells, the compound under study was added at a preset dilution, $150 \mu \mathrm{L}$ to each well. The dilutions of the compounds were prepared immediately in nutrient media; $5 \%$ DMSO that does not induce inhibition of cells at this concentration was added for better solubility. The experiments were repeated three times. Intact cells cultured in parallel with experimental cells were used as a control.

\section{Anticoagulant and anti-aggregation activities study}

The in vitro experiments were performed using the blood of healthy male donors aged 18-24 years (total 54 donors). The study was approved by the Ethics Committee of Federal State Budgetary Educational Institution of Higher Education at the Bashkir State Medical University of the Ministry of Health of Russian Federation (No.2 dated 17.10.2012). Informed consent was obtained from all participants before blood sampling. The blood was collected from the cubital vein using the system of vacuum blood collection BD Vacutainer (Becton, Dickinson and Company, USA). A 3.8 \% sodium citrate solution in a 9:1 ratio was used as a venous blood stabiliser. The study of the effect on platelet aggregation was performed using the Born method [33] using the aggregometer "AT-02» (SPC Medtech, Russia). The assessment of antiplatelet activity of the studied compounds and reference preparations was started with the final concentration of $2 \times 10^{-3} \mathrm{~mol} / \mathrm{L}$. Adenosine diphosphate (ADP; $20 \mu \mathrm{g} / \mathrm{mL}$ ) and collagen $(5 \mathrm{mg} / \mathrm{mL}$ ) manufactured by Tehnologia-Standart Company, Russia, were used as inducers of aggregation. The study on the anticoagulant activity was performed by standard recognised clotting tests using the optical two-channel automatic analyser of blood coagulation Solar CGL 2110 (CJSC SOLAR, Belarus). The following parameters were studied: activated partial thromboplastin time (APTT), prothrombin time (PT) and fibrinogen concentrations according to the Clauss method. The determination of anticoagulant activity of the studied compounds and reference preparation was performed in a concentration of $5 \times 10^{-4} \mathrm{~g} / \mathrm{mL}$ using the reagents manufactured by Tehnologia-Standart Company (Barnaul, Russia). The results of the study were processed using the statistical package Statistica 10.0 (StatSoft Inc, USA). The Shapiro-Wilk's test was used to check the normality of actual data distribution. The form of distribution of the data obtained differed from the normal one; therefore, non-parametric methods were used for further analysis. The data were presented as medians and 25 and 75 percentiles. Analysis of variance was conducted using Kruskal-Wallis test. A p value of 0.05 was considered statistically significant.

\section{Antiphytopathogenic activity study}

Plant pathogenic bacterial strains Micrococcus luteus B-109, Pectobacterium atrosepticum 1043, Pectobacterium carotovorum subsp. carotovorum MI, Pseudomonas fluorescens EL-2.1, and Xanthomonas campestris B-610 and fungal strain Fusarium oxysporum IBPPM 543 were obtained from the specialized scientific culture collection of IBPPM RAS (WFCC no. 975, WDCM no. 1021) (CM IBPPM). Pathogenic fungus Phytophthora cactorum VKM F-985 provided by the All-Russian Collection of Microorganisms (VKM) and deposited at A.E. Favorsky Irkutsk Institute of Chemistry, SB RAS, was also used as test organism. Bacteria 
M. luteus, P. carotovorum subsp. carotovorum, P. atrosepticum, and Ps. fluorescens were grown in meatpeptone medium (BP), and $X$. campestris was grown in the medium with glucose, yeast extract, and calcium carbonate (GYCa). Solid media contained Bacto agar (18 g/L); $\mathrm{pH}$ was adjusted to 7.2-7.4. All bacterial cultures were grown at $28^{\circ} \mathrm{C}$. The mycelial cultures of $F$. oxysporum and $P$. cactorum were grown on a glucose-peptone-yeast (GPY) nutrient medium at $27^{\circ} \mathrm{C}$. For inoculum preparation, both fungal strains were initially grown on the agar GPY in Petri dishes and then transferred into the seed medium by punching out 5 $\mathrm{mm}$ of the agar plate culture with a self-designed cutter.

Antibacterial and antifungal activities of the compounds were explored using the agar diffusion method and the technique of a phytopathogen radial growth inhibition. Method of diffusion in agar (measuring the diameter of growth inhibition zones) was used for determining the bactericidal activity. The 6-mm wells were made in ager medium (GYCa for Xanthomonas campestris or BP for other bacteria). Bacterial suspensions were distributed over the agar surface, and the tested compound's solution $(150 \mu l)$ was added to each well. The width of growth inhibition zones around the wells was determined after incubation for 36-40 h.

For the fungicidal activity analysis, radial growth (colony diameters) of the fungi on a solid medium in the absence and in the presence of the compounds $\mathbf{3 a}, \mathbf{c}-\mathbf{g}$ solutions at various concentrations were compared. The method consisted of the following: sterile, melted and then cooled to about $60^{\circ} \mathrm{C}$ GPY agar medium $(20.0 \mathrm{ml})$ was mixed with the precisely measured volumes of the solutions under question, and poured into a sterile Petri dish ( $90 \mathrm{~mm}$ i.d.). After solidification of GPY agar, the media were inoculated by the fungus using 10-day-old cultures of $F$. oxysporum or $P$. cactorum. The inoculation was done by transferring a 5-mm (i.d.) GPY-agar block covered with mycelium to the center of the Petri dish followed by incubation in a thermostat at $27^{\circ} \mathrm{C}$. The fungicidal effect was scored by the size of mycelium colony on a Petri dish compared to the control without fungicidal admixtures to GPY agar. Each treatment was performed in at least four replicates in two independent experiments. The observation period ended when the control Petri dish was filled with mycelium (usually after 12 days). The inhibition of the phytopathogen colony growth by the compounds $\mathbf{3 a , c - g}$ or fludioxonil solutions was calculated as a percentage by which the mycelium radial propagation was decreased compared to the unaffected control, the latter was taken as $100 \%$ of growth (or zero percent of inhibition). The $\mathrm{EC}_{50}$ value was calculated as the compound concentration at which the radial growth of the fungus colony was decreased by $50 \%$ relative to the nonfungicidal control, according to the formula $\mathrm{EC}_{50}=50 \mathrm{C} / \mathrm{I}$ based on the approach developed e.g., in [34,35].

The solutions of tested compounds were prepared with a concentration of $2 \mathrm{mmol} / \mathrm{l}$ (stock solution). For comparison, test compounds were also commonly applied disinfecting agents and antibiotics.

\section{Results and Discussion}

\section{Chemistry}

The synthesis of target compounds is based on our previously developed approach [24-30] and is carried out in two stages (Fig. 1). At the first stage, hydrazide $\mathbf{1}$ (an analog of the Girard's reagent T) was obtained for the first time, containing three ethyl groups at the quaternized nitrogen atom. Further, this hydrazide was involved in the condensation with isatin derivatives bearing a phenolic fragment in position 1 and substituents of different nature in the benzo fragment of the heterocycle. The reaction proceeds in ethanol at reflux temperature for 3 hours in the presence of trifluoroacetic acid as a catalyst. After easy workup, the desired reaction products were isolated in pure form with high yields (89-97\%). The structure of all obtained hydrazones 3a-g was proved using NMR and IR spectroscopy. Thus, the IR spectra of the new 
compounds contain narrow, intense absorption bands in the region of $3600-3630 \mathrm{~cm}^{-1}$ and broad bands of medium intensity at $3210-3380 \mathrm{~cm}^{-1}$, corresponding to the stretching vibrations of $\mathrm{O}-\mathrm{H}$ and $\mathrm{N}-\mathrm{H}$ bonds, respectively. The presence of these functional groups is also confirmed by the data of ${ }^{1} \mathrm{H}$ NMR spectra, in which the signal of the proton of the hydroxyl group appears in the region of $\sim 5.2 \mathrm{ppm}$, and the signal of the hydrazone proton in the lowest fields at $\sim 12.8 \mathrm{ppm}$.

\section{Antimicrobial activity evaluation}

Synthesized compounds were further evaluated for antimicrobial activity against test microorganisms: Staphylococcus aureus ATCC 209p (Sa), Bacillus cereus ATCC 8035 (BC), Escherichia coli CDC F-50 (EC), Enterococcus faecalis (Ef), Pseudomonas aeruginosa ATCC 9027, Aspergillus niger BKMF-1119, Trichophyton mentagrophytes var. gypseum 1773, and Candida albicans 855-653 including methicillin-resistant strains of S. aureus (MRSA 1 and MRSA 2). The minimum inhibitory (MIC) and minimum bactericidal (MBC) concentrations of ammonium salts were determined against these pathogens (Table 1). Due to the lack of activity of compounds 3a-g against Gram-negative bacterial strains and some fungi, the corresponding data are not shown.

Table 1. Antimicrobial activity of compounds $3 a-g^{*}$.

\begin{tabular}{|c|c|c|c|c|c|c|}
\hline \multirow{2}{*}{ Compound } & \multicolumn{6}{|c|}{$\mathrm{MIC} / \mathrm{MBC}, \mu \mathrm{M}$} \\
\hline & $\mathrm{Sa}$ & $B C$ & $E f$ & MRSA-1 & MRSA-2 & $\mathrm{Ca}$ \\
\hline $3 a$ & $\begin{array}{l}6.5 \pm 0.5 / \\
13.0 \pm 1.2\end{array}$ & $52 \pm 4.7 /-$ & - & nd* & nd & $-* *$ \\
\hline $3 b$ & $\begin{array}{l}3.2 \pm 0.2 / \\
25.4 \pm 2.1\end{array}$ & $\begin{array}{c}25.4 \pm 1.9 / \\
203 \pm 16\end{array}$ & - & $\begin{array}{c}50.8 \pm 4.1 / \\
203.2 \pm 16.4\end{array}$ & $\begin{array}{c}25.4 \pm 2.3 / \\
50.8 \pm 4.1\end{array}$ & - \\
\hline $3 c$ & $\begin{array}{c}3.1 \pm 0.2 \\
/ 6.2 \pm 0.5\end{array}$ & $\begin{array}{l}24.8 \pm 1.9 / \\
99.3 \pm 8.2\end{array}$ & - & $\begin{array}{c}49.7 \pm 3.9 / \\
99.3 \pm 8.3\end{array}$ & $\begin{array}{c}24.8 \pm 2.2 / \\
99.3 \pm 8.3\end{array}$ & - \\
\hline $3 d$ & $\begin{array}{l}3.1 \pm 0.2 / \\
12.4 \pm 1.1\end{array}$ & $\begin{array}{c}49.6 \pm 3.9 / \\
198.5 \pm 15.7\end{array}$ & $\begin{array}{c}49.6 \pm 3.9 / \\
49.6 \pm 3.9\end{array}$ & $\begin{array}{l}6.2 \pm 0.5 / \\
12.4 \pm 1.2\end{array}$ & $\begin{array}{l}6.2 \pm 0.5 / \\
49.6 \pm 3.8\end{array}$ & $198.5 \pm 15.5 /-$ \\
\hline $3 e$ & $\begin{array}{l}8.9 \pm 0.7 / \\
17.7 \pm 1.5\end{array}$ & $\begin{array}{c}71 \pm 6.2 / \\
283.7 \pm 22.7\end{array}$ & - & nd & nd & - \\
\hline $3 f$ & $\begin{array}{r}48.3 \pm 3.9 / \\
96.7 \pm 7.6\end{array}$ & $397 \pm 31.7 /-$ & - & nd & nd & - \\
\hline $3 g$ & $\begin{array}{l}11 \pm 0.9 / \\
21.9 \pm 1.8\end{array}$ & $\begin{array}{l}43.7 \pm 3.5 / \\
87.4 \pm 7.2\end{array}$ & - & nd & nd & - \\
\hline Norfloxacin & $\begin{array}{l}7.5 \pm 0.5 / \\
7.5 \pm 0.6\end{array}$ & $\begin{array}{l}24.4 \pm 2.1 / \\
24.4 \pm 2.1\end{array}$ & $\begin{array}{l}7.5 \pm 0.5 / \\
7.5 \pm 0.6\end{array}$ & $391.4 \pm 30 /$ na§ & $30.0 \pm 2.6 / \mathrm{na}$ & \\
\hline
\end{tabular}

* were not determined (compounds possess low activity); $\S$ no activity; ${ }^{* *}$ means $>500$

The initial study of antimicrobial activity showed that triethylammonium derivatives 3a-g, like their trimethylammonium analogs [24-27], selectively act on Gram-positive pathogenic bacterial strains with high activity. Compared with norfloxacin against $S a$, compounds 3a-e (MIC 8.9-3.1 $\mu \mathrm{M}$ ) turned out to be the best in bacteriostatic effect, and hydrazones $3 \mathbf{b}, \mathbf{c}(\mathrm{MIC} \sim 25 \mu \mathrm{M})$ were the best against $B c$. According to the bactericidal action derivative $\mathbf{3 c}$ was determined as the leader compound, containing an ethyl radical in position 7 with an $\mathrm{MBC}$ of $6.2 \mu \mathrm{M}$, better than that of the reference drug. It should be noted that only compound 3d showed antimicrobial activity against Enterococcus faecalis that often causes a wide range of nosocomial human infections. It is especially important to note that three representatives of this series compounds $\mathbf{3 b} \mathbf{b} \mathbf{d}$ - showed high activity against both types of MRSA used. In this case, the most effective was the most lipophilic hydrazone $\mathbf{3 d}$, containing two methyl groups in the aromatic fragment of the heterocycle. This compound also showed moderate activity against the yeast-like fungus Candida albicans. 
Thus, the data obtained showed that acylhydrazones bearing electron-donor alkyl groups in the benzo fragment possess the best activity against both museum and methicillin-resistant bacterial strains.

An important step in the determination of the biological activity of new chemical compounds is the assessment of their cytotoxic action in relation to mammalian cells. The ability of the investigated compound to cause the destruction of human erythrocytes illustrates its toxic effect on the internal environment of the body. The hemolysis assay is a simple screening test, the results of which can help in the study of cytotoxicity in more complex models. Such experimental models can be the cell lines obtained from various organs and tissues of a person and allowing to adequately assessing the effect of new potential drugs on cell metabolism. In this regard, the studied compounds were tested for cytotoxicity against blood erythrocytes and the human hepatocytes (Chang liver cell lines (Fig. 3). Hemolytic and cytotoxic activity data are represented by $\mathrm{HC}_{50}$ and $\mathrm{IC}_{50}$ values. It can be seen that all compounds $\mathbf{3 a - 3} \mathbf{g}$ in the range of tested concentrations did not have high hemolytic and cytotoxic activity. $\mathrm{HC}_{50}$ concentrations were 72.2-243.8 $\mu \mathrm{M} ; \mathrm{IC}_{50}-113-168 \mu \mathrm{M}$. From the point of view of the effect on red blood cells, the least toxic compound is compound $\mathbf{3} \mathbf{b}$ containing methyl group at position 7 of the aromatic fragment. Reference drugs gramicidin $\mathrm{S}$ and doxorubicin turned out to be much more toxic to red blood cells and liver cells.

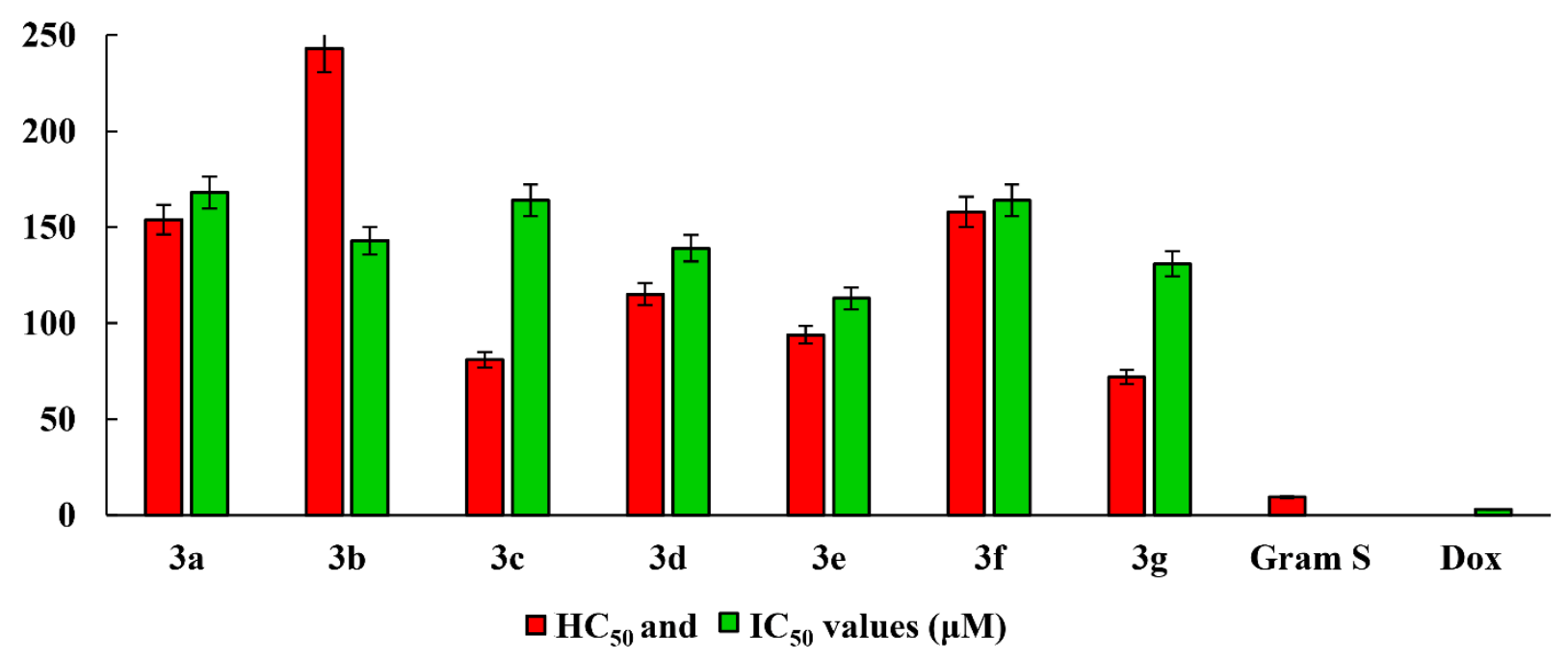

Figure 3. Hemolytic and cytotoxic activity of 3a-g

The selectivity of compounds for microbial cells is an important criterion for assessing the cytotoxic effect. This indicator is characterized by the value of the selectivity index (SI), which for the leading compounds $\mathbf{3 b}, \mathbf{3} \mathbf{c}$, and $\mathbf{3 d}$ was calculated as the ratio between the $\mathrm{HC}_{50}$ value for erythrocytes $\left(\mathrm{IC}_{50}\right.$ for eukaryotic cells) and the MIC value for bacterial cells (Fig. 4). It can be seen that with respect to the $S$. aureus $209 \mathrm{P}$ test strain, all tested compounds exhibit a sufficiently high selectivity. Compound $\mathbf{3 d}$ bearing two methyl groups demonstrated the most significant selectivity against resistant strains MRSA-1 and MRSA-2 compared to erythrocytes and hepatocytes. Its selectivity index was 3-8 times higher than that of compounds $\mathbf{3 b}$ and $\mathbf{3 c}$. 

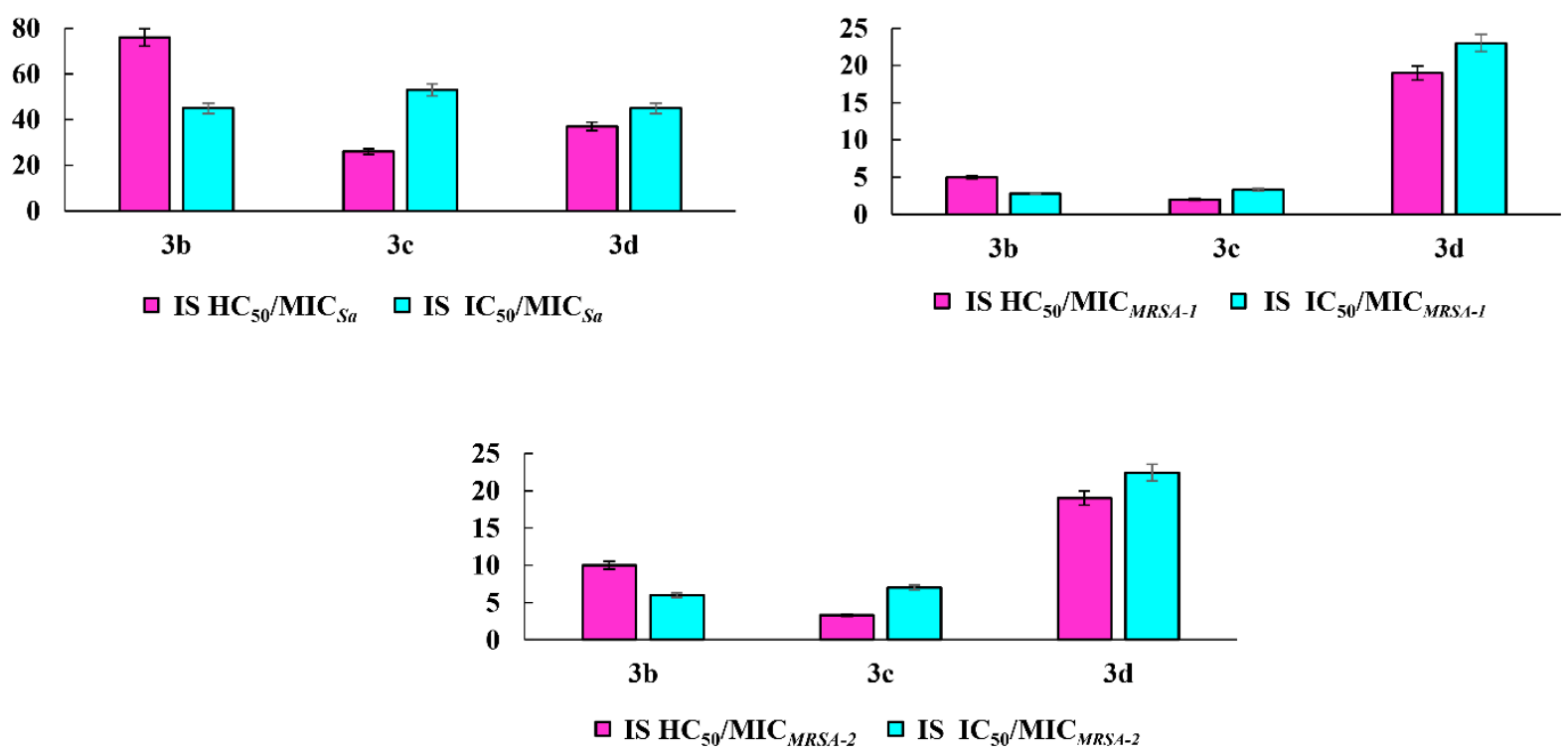

Figure 4. Selectivity of $\mathbf{3 b}, \mathbf{3 c}$ and $\mathbf{3 d}$ for bacteria (S. aureus 209, MRSA-1and MRSA-2) compared to red blood cells and Chang liver cells.

Anticoagulant and anti-aggregation activities evaluation

The development of new drug candidates is a multi-stage process that requires consideration of the influence of many factors, including the level of toxicity and the presence of side effects. There are many examples of drug recalls from the market in world practice, which gradually reveals serious side effects associated, for example, with the risk of developing cardiovascular diseases [36,37]. In this regard, it seemed appropriate and important to assess the effect of the newly synthesized isatin-3-acylhydrazones on the hemostatic system. In this work, we carried out a primary study of the anti-aggregation and anticoagulant activity of compounds 3a-g (Table 2).

Table 2. Anticoagulant and anti-aggregation activity of compounds 3a-g

\begin{tabular}{|c|c|c|c|}
\hline \multirow{2}{*}{ Compound } & \multicolumn{2}{|c|}{ Platelets aggregation, $\%$ of control } & \multirow{2}{*}{$A P T T^{\$ \$}, \%$ of control } \\
\hline & $A D P^{\$}$ & Collagen & \\
\hline $3 a$ & $-10.5(8.7-13.9)^{*}$ & $-9.4(8.5-12.3)^{*}$ & $+5.2(4.1-7.6)^{*},+$ \\
\hline $3 b$ & $-9.7(7.4-12.3)^{*}$ & $-10.3(9.6-12.5)^{*}$ & $+7.3(6.5-9.6)^{*},+$ \\
\hline $3 c$ & $-13.7(11.5-15.1)^{* *}$ & $-12.5(9.8-14.3)^{*}$ & $+11.2(7.9-13.1)^{*}, \dagger$ \\
\hline $3 d$ & $-9.0(7.5-10.6)^{*}, \#$ & $-8.5(7.2-12.3)^{*}, \#$ & $+4.8(3.7-6.9)+\dagger$ \\
\hline $3 e$ & -0.5 (0.2-0.9)\#\# & -2.4 (1.7-3.5)\#\# & $+3.2(2.8-5.4)^{\dagger+}$ \\
\hline $3 f$ & $-4.6(3.7-5.3)^{*}, \#$ & $-4.3(3.4-5.6)^{*}, \#$ & $+10.3(8.5-12.7)^{*}, \dagger$ \\
\hline $3 g$ & $-10.2(8.6-12.2)^{*}$ & $-8.9(7.5-10.3)^{*}, \#$ & $+8.6(6.1-10.9)^{*},+$ \\
\hline Acetylsalicylic acid & $-13.7(10.8-16.4)^{*}$ & $-14.7(12.1-16.3)^{* *}$ & - \\
\hline Heparin sodium & - & - & $+20.3(19.7-21.4)^{* *}$ \\
\hline
\end{tabular}

The compounds demonstrated the varying extent of the effect on the plasmatic component of the haemostasis system that manifested only by a change in the parameter APTT of the intrinsic coagulation pathway. Compounds $\mathbf{3 c}$, $\mathbf{f}$ demonstrated anticoagulant activity $\geq 10 \%(p<0.05)$. Regarding the impact on platelet aggregation, the compounds demonstrated similar activity on both aggregation inductors. Compounds 3a-c,g demonstrated antiaggregatory activity in vitro at the level of acetylsalicylic acid. The 
most promising active compound is 7-ethyl substituted analog 3c. Among the obtained series of new compounds, this hydrazone is the most active.

\section{Antiphytopathogenic activity evaluation}

To expand the range of possible practical applications of isatin derivatives, synthesized compounds were examined for their antibacterial and antifungal effects against test organisms. Bacterial pathogens isolated from the plants microenvironment and harvested vegetables frequently include Micrococcus luteus, Pseudomonas fluorescens, Pectobacterium carotovorum (Erwinia carotovora), Xanthomonas campestris, and Pectobacterium atrosepticum (Erwinia carotovora subsp. atrosepticum) [38-40]. Fungal pathogens cause $70-80 \%$ of all plant diseases [41], possessing a potentiality of causing large-scale disease outbreaks in a very limited period of time. Among the diverse mycelial pathogenic fungi, those from the genera Fusarium and Phytophthora are among the most destructive plant pathogens known, have broad host ranges, and are capable of causing crop losses and eventual collapse of whole infected plants [42]. $F$. oxysporum is referred to as the aggressive pathogen among Fusarium species, and, in particular, different branches of the food industry are extremely conscious of Fusarium infections of cereals [43]. Phytophthora cactorum is a causative agent of phytophthora blight of ginseng (Panax ginseng), a plant that is very useful for conventional medicine to treat various diseases, including cancer [44].

Along with the solutions of $3 \mathrm{a}, \mathrm{c}-\mathrm{g}$, test compounds were sodium hypochlorite $(1000 \mu \mathrm{g} / \mathrm{ml})$, chlorohexidin $(500 \mu \mathrm{g} / \mathrm{ml})$, and norfloxacin $(500 \mu \mathrm{g} / \mathrm{ml})$, a synthetic fluoroquinolone with broad-spectrum antibacterial activity against most bacteria. A commercial widely used fungicide fludioxonil capable of inhibiting the pathogenic fungi mycelium propagation served for the purpose of comparison in the course of the fungicidal effect assays. Under laboratory conditions, the assessment of the phytopathogenic fungi resistance to this fungicide is referred to be conducted at its concentrations from 0.1 to $10 \mu \mathrm{g} / \mathrm{ml}$ [45].

The results of determining the bactericidal activity against M. luteus B-109, P. atrosepticum 1043, $P$. carotovorum subsp. carotovorum MI, Ps. fluorescens EL-2.1, X. campestris B-610 showed non-zero activity against bacterial test systems of all the compounds tested (Table 3).

Table 3. Bactericidal activity of hydrazones $(2 \mathrm{mM} / \mathrm{L})$ studied*.

\begin{tabular}{|c|c|c|c|c|c|}
\hline \multirow[b]{2}{*}{ Compound** } & \multicolumn{5}{|c|}{ Bacterial phytopathogen } \\
\hline & M. luteus & P. atrosepticum & $\begin{array}{l}\text { P. carotovorum } \\
\text { subsp. } \\
\text { carotovorum }\end{array}$ & $\begin{array}{c}\text { Ps. } \\
\text { fluorescens }\end{array}$ & $\begin{array}{c}X . \\
\text { campestris }\end{array}$ \\
\hline $3 a$ & 9 & 8 & 10 & 9 & 10 \\
\hline $3 c$ & 10.5 & 9 & 9 & 8 & 11 \\
\hline 3d & 8 & 8 & 8 & 9 & 8 \\
\hline $3 e$ & 13 & 15 & 10 & 9 & 11 \\
\hline $3 f$ & 10 & 10 & 5 & 10 & 7.5 \\
\hline $3 g$ & 7 & 9 & 9 & 8.5 & 8 \\
\hline Norfloxacin, $500 \mu \mathrm{g} / \mathrm{mL}$ & 7 & 7 & 8 & 8 & 7 \\
\hline $\begin{array}{c}\text { sodium hypochlorite, } \\
1000 \mu \mathrm{g} / \mathrm{mL}\end{array}$ & 2.5 & 4 & 3 & 4 & 4 \\
\hline $\begin{array}{c}\text { Chlorohexidin, } 500 \\
\mu \mathrm{g} / \mathrm{mL}\end{array}$ & 5 & 4 & 5 & 4 & 5 \\
\hline
\end{tabular}

* shows the values of the width of the inhibition zone $(\mathrm{mm})$, averaged over the results of 3 experiments; ${ }^{* *}$ compound $\mathbf{3 b}$ was not tested due to the formation of precipitate at the solution preparation

Compounds 3a, c-g showed high antibacterial activity in this experiment. Only in a few cases was the inhibition zone width of 5 and $7.5 \mathrm{~mm}$ (3f versus $P$. carotovorum and $X$. campestris, respectively), $7 \mathrm{~mm}$ ( $3 \mathrm{~g}$ versus $M$. luteus) found. Other drugs with an even more pronounced bactericidal effect formed the growth 
of phytopathogens inhibition zone from 8 to $15 \mathrm{~mm}$ (Table 4).

Table 4. Comparative bactericidal activity of compounds 3a, c-g (2 mM/L).

\begin{tabular}{|c|c|c|c|c|c|c|}
\hline \multirow{2}{*}{ Bacterial test system } & \multicolumn{6}{|c|}{ Inhibition zone width $(\mathrm{mm})$, not less } \\
\hline & 15 & 13 & 11 & 10 & 9 & 8 \\
\hline Micrococcus luteus B-109 & - & $3 e$ & - & $3 c>3 f$ & 3a & $3 d$ \\
\hline Pectobacterium atrosepticum 1043 & $3 e$ & - & - & $3 f$ & $3 c, 48$ & 3a, 3d \\
\hline $\begin{array}{l}\text { Pectobacterium carotovorum } \\
\text { subsp. carotovorum } \mathrm{MI}\end{array}$ & - & - & - & $3 e, 3 a$ & $3 c, 3 g$ & $3 d$ \\
\hline Pseudomonas fluorescens EL-2.1 & - & - & - & $3 f$ & 3e, 3a, 3d & $3 g>3 c$ \\
\hline Xanthomonas campestris B-610 & - & - & $3 e, 3 c$ & $3 a$ & - & 3d, 3g \\
\hline
\end{tabular}

Taking into account the data in Table 4, it is quite conditionally possible to arrange the studied $2 \mathrm{mM}$ solutions of compounds 3a,c-g in decreasing order of activity as follows: $\mathbf{3 e}>\mathbf{3 c}>\mathbf{3 a}>\mathbf{3 d}>\mathbf{3 g}>\mathbf{3 f}$. Thus, with respect to the phytopathogens used, the best activity was shown by acylhydrazone 3e containing a bromine atom at position 4 of the heterocycle.

Screening for the manifestation of antifungal properties of compounds 3a,c-g, introduced into the agar medium to cultivate the fungus $F$. oxysporum, was carried out in the concentration range of $6-43 \mu \mathrm{g} / \mathrm{mL}$ (Table 5).

Table 5. Fungicidal activity of compounds 3a,c-g against Fusarium oxysporum IBPPM 543.

\begin{tabular}{|c|c|c|c|c|c|c|}
\hline \multirow[t]{2}{*}{ Compound } & \multirow[t]{2}{*}{$\mathrm{C}, \mu \mathrm{g} / \mathrm{mL}$} & \multicolumn{4}{|c|}{$\begin{array}{l}\text { Inhibition value, I (\%)*, } \\
\text { at the age of the fungus (days) }\end{array}$} & \multirow[t]{2}{*}{$\begin{array}{c}\mathrm{EC}_{50}, \mu \mathrm{g} / \mathrm{mL} \\
\text { at day } 7\end{array}$} \\
\hline & & 3 & 5 & 7 & 9 & \\
\hline \multirow{4}{*}{$3 a$} & 6.02 & 11 & 4 & 9 & 0 & \multirow{4}{*}{33.44} \\
\hline & 12.04 & 14 & 12 & 18 & 3 & \\
\hline & 24.08 & 24 & 16 & 27 & 4 & \\
\hline & 36.12 & 28 & 24 & 30 & 12 & \\
\hline \multirow{4}{*}{$3 c$} & 6.30 & 2 & 11 & 30 & 17 & \multirow{4}{*}{10.50} \\
\hline & 12.60 & 24 & 26 & 33 & 23 & \\
\hline & 25.20 & 31 & 33 & 47 & 27 & \\
\hline & 37.80 & 44 & 42 & 59 & 38 & \\
\hline \multirow{4}{*}{$3 d$} & 6.30 & 0 & 5 & 5 & 0 & \multirow{4}{*}{48.46} \\
\hline & 12.60 & 8 & 12 & 13 & 2 & \\
\hline & 25.20 & 17 & 15 & 20 & 8 & \\
\hline & 37.80 & 22 & 18 & 24 & 9 & \\
\hline \multirow{4}{*}{$3 e$} & 6.81 & 11 & 13 & 19 & 6 & \multirow{4}{*}{17.92} \\
\hline & 13.62 & 14 & 18 & 22 & 9 & \\
\hline & 27.24 & 19 & 19 & 25 & 20 & \\
\hline & 40.86 & 40 & 37 & 43 & 29 & \\
\hline \multirow{4}{*}{$3 f$} & 6.47 & 13 & 11 & 10 & 9 & \multirow{4}{*}{30.81} \\
\hline & 12.94 & 26 & 23 & 21 & 10 & \\
\hline & 25.88 & 28 & 27 & 32 & 12 & \\
\hline & 38.82 & 29 & 28 & 34 & 18 & \\
\hline \multirow{4}{*}{$3 g$} & 7.15 & 0 & 4 & 5 & 4 & \multirow{4}{*}{55.00} \\
\hline & 14.30 & 9 & 4 & 11 & 5 & \\
\hline & 28.60 & 11 & 7 & 26 & 10 & \\
\hline & 42.90 & 31 & 27 & 32 & 13 & \\
\hline Fludioxonil & 10 & 38 & 23 & 6 & 4 & 83.33 \\
\hline
\end{tabular}

* the average values are given; the standard deviation did not exceed 0.03 from the given value. 
The antifungal properties of compounds $3 a, c-g$, introduced into the agar medium to cultivate the fungus $P$. cactorum, were studied in the concentration range $1-15 \mu \mathrm{g} / \mathrm{mL}$. The amount of inhibition of fungal growth was expressed as a percentage, taking into account that the quantitative characteristic of the absence of inhibition is expressed as $0 \%$ (table 6).

Table 6. Fungicidal activity of compounds 3a,c-g against Phytophthora cactorum VKM F-985.

\begin{tabular}{|c|c|c|c|c|c|c|c|}
\hline \multirow[t]{2}{*}{ Compound } & \multirow[t]{2}{*}{$C, \mu \mathrm{g} / \mathrm{mL}$} & \multicolumn{5}{|c|}{$\begin{array}{l}\text { Inhibition value, } I(\%)^{*} \\
\text { at the age of the fungus (days) }\end{array}$} & \multirow{2}{*}{$\begin{array}{c}\mathrm{EC}_{50}, \mu \mathrm{g} / \mathrm{mL} \\
\text { at day } 7\end{array}$} \\
\hline & & 3 & 5 & 7 & 9 & 12 & \\
\hline \multirow[t]{4}{*}{$3 a$} & 3.01 & 4 & 9 & 15 & 1 & 0 & \multirow{4}{*}{10.03} \\
\hline & 6.02 & 13 & 21 & 22 & 4 & 5 & \\
\hline & 9.03 & 17 & 22 & 25 & 4 & 5 & \\
\hline & 12.04 & 40 & 47 & 49 & 41 & 26 & \\
\hline \multirow[t]{5}{*}{$3 c$} & 1.26 & 17 & 28 & 30 & 12 & 3 & \multirow{5}{*}{2.10} \\
\hline & 3.15 & 29 & 31 & 38 & 20 & 16 & \\
\hline & 6.30 & 33 & 44 & 45 & 28 & 20 & \\
\hline & 9.45 & 39 & 45 & 48 & 41 & 36 & \\
\hline & 12.60 & 50 & 56 & 61 & 58 & 48 & \\
\hline \multirow[t]{5}{*}{$3 d$} & 1.26 & 18 & 17 & 5 & 0 & 0 & \multirow{5}{*}{11.25} \\
\hline & 3.15 & 23 & 18 & 14 & 6 & 5 & \\
\hline & 6.30 & 29 & 19 & 15 & 8 & 7 & \\
\hline & 9.45 & 31 & 20 & 17 & 9 & 8 & \\
\hline & 12.60 & 50 & 50 & 51 & 48 & 35 & \\
\hline \multirow[t]{5}{*}{$3 e$} & 1.36 & 8 & 14 & 22 & 10 & 3 & \multirow{5}{*}{3.10} \\
\hline & 3.41 & 13 & 21 & 34 & 12 & 5 & \\
\hline & 6.81 & 17 & 33 & 38 & 16 & 7 & \\
\hline & 10.22 & 39 & 40 & 53 & 28 & 18 & \\
\hline & 13.62 & 45 & 62 & 72 & 70 & 66 & \\
\hline \multirow[t]{5}{*}{$3 f$} & 1.29 & 17 & 11 & 2 & 0 & 0 & \multirow{5}{*}{8.99} \\
\hline & 3.24 & 33 & 19 & 18 & 1 & 0 & \\
\hline & 6.47 & 35 & 23 & 20 & 8 & 1 & \\
\hline & 9.71 & 41 & 36 & 32 & 20 & 16 & \\
\hline & 12.94 & 59 & 55 & 53 & 48 & 30 & \\
\hline \multirow[t]{5}{*}{$3 g$} & 1.43 & 30 & 29 & 15 & 1 & 0 & \multirow{5}{*}{4.77} \\
\hline & 3.58 & 38 & 29 & 22 & 5 & 0 & \\
\hline & 7.15 & 40 & 33 & 26 & 14 & 11 & \\
\hline & 10.73 & 48 & 43 & 41 & 31 & 26 & \\
\hline & 14.30 & 51 & 48 & 46 & 41 & 28 & \\
\hline Fludioxonil & 10 & 46 & 38 & 18 & 12 & 9 & 27.78 \\
\hline
\end{tabular}

All compounds 3a,c-g showed an antagonistic effect against $P$. cactorum, superior to fludioxonil from 2.5 (3d) to 13.2 (3c) times by seven days of the fungus growth. At the same culture age of $F$. oxysporum, almost all compounds of this series outperformed fludioxonil in antifungal effect by up to 7.9 times (hydrazone 3c). It is important to note that fludioxonil showed the greatest antifungal effect at the age of both cultures three days, and then the fungicidal effect of the commercial drug was significantly reduced (Tables 5, 6). At the same time, the fungicidal properties of compounds $\mathbf{3 e}, \mathbf{3 a}, \mathbf{3} \mathbf{c}$ increased during the development of the mycelium. The inhibition value I by these drugs after 5-9 days of $P$. cactorum growth increased by a maximum of $27 \%$ (3e), in F. oxysporum - by $28 \%$ (3c). Moreover, in the case of using the Fusarium test system, an increase in antifungal ability in the dynamics of the experiment was revealed in the entire group 3a,c-g (Table 6). In decreasing order of activity against F. oxysporum, the following series is obtained: $\mathbf{3 c}>$ $\mathbf{3 e}>\mathbf{3 f}>\mathbf{3 a}>\mathbf{3 d}>\mathbf{3 g}$. For $P$. cactorum, the series is as follows: $\mathbf{3 c}>\mathbf{3 e}>\mathbf{3 g}>\mathbf{3 f}>\mathbf{3 a}>\mathbf{3 d}$. Thus, newly synthesized isatin derivatives of $\mathbf{3 a}, \mathbf{c}-\mathbf{g}$, possessing significant antibacterial activity, were able to 
significantly inhibit the growth of pathogenic fungi $F$. oxysporum and $P$. cactorum on a dense medium. First of all, these are 4-bromo- (3e) and 7-ethyl derivatives (3c) - "leaders" in all sequences of the location of compounds in terms of antiphytopathogenic activity: against pathogenic bacteria, against fungi $F$. oxysporum and $P$. cactorum.

\section{Conclusions}

A number of new isatin-3-acylhydrazones containing a triethylammonium fragment have been synthesized, and their multiple biological profiles were revealed. The study of antimicrobial properties showed that the compounds obtained have selective activity against Staphylococcus aureus and Bacillus cereus. Derivatives containing donor alkyl substituents showed bacteriostatic activity two times better than norfloxacin, and the 7-ethyl analog was slightly better than the reference drug in terms of its bactericidal effect. The results obtained showed low toxicity of new compounds towards healthy human cells (red blood cells, hepatocytes) and the absence of a negative effect on some factors of hemostasis. The study of antiphytopathogenic activity showed that 4-bromine (3e) and 7-ethyl (3c) analogs have high activity against a number of dangerous bacterial (Micrococcus luteus and Pectobacterium atrosepticum) and fungal ( $F$. oxysporum and $P$. cactorum) pathogens that exceeds those for reference drugs norfloxacin, chlorohexidine and fludioxonil respectively. Thus, the data obtained indicate a high potential for the development of effective biocompatible drugs for both pharmaceutical and agricultural purposes.

Acknowledgements: The authors thank the Spectral and Analytical Joint Center (Kazan Scientific Center, Russian Academy of Sciences) for technical support. Part of the work on the synthesis and study of antimicrobial, hemolytic and cytotoxic activities (A. Bogdanov, A. Voloshina, A. Lyubina, S. Amerkhanova) was carried out within the framework of the state assignment of the Federal Research Center KSC RAS. Research on antiphytopathogenic activity was completed in the framework of theme No. 121031100266-3 of the Program of fundamental research of the Russian Academy of Sciences.

Conflict of interest: The authors declare no conflict of interest

\section{References}

[1] M.E. Welsch, S.A. Snyder, B.R. Stockwell. Privileged scaffolds for library design and drug discovery. Current Opinion in Chemical Biology 14 (2010) 347-361. https://doi.org/10.1016/j.cbpa.2010.02.018.

[2] C. Melis, R. Meleddu, A. Angeli, S. Distinto, G. Bianco, C. Capasso, F. Cottiglia, R. Angius, C.T. Supuran, E. Maccioni. Isatin: a privileged scaffold for the design of carbonic anhydrase inhibitors. Journal of Enzyme Inhibition and Medicinal Chemistry 32 (2017) 68-73. https://doi.org/10.1080/14756366.2016.1235042.

[3] A.V. Bogdanov, V.F. Mironov. Advances in the synthesis of isatins: a Survey of the last decade. Synthesis 50 (2018) 1601-1609. https://doi.org/10.1055/s-0036-1591946.

[4] S.Z. Drmanić, P. Petrović, D.R. Brkić, A.D. Marinković, J.B. Nikolić. A survey on the characterization and biological activity of isatin derivatives. Journal of the Serbian Chemical Society 85 (2020) 9791000. https://doi.org/10.2298/JSC200320020D.

[5] P. Brandao, C. Marques, A.J. Burke, M. Pineiro. The application of isatin-based multicomponentreactions in the quest for new bioactive and druglike molecules. European Journal of Medicinal Chemistry 211 (2021) 113102. https://doi.org/10.1016/j.ejmech.2020.113102.

[6] Y.-Zh. Zhang, H.-Zh. Du, H.-L. Liu, Q.-S. He, Zh. Xu. Isatin dimers and their biological activities. Archiv der Pharmazie (Weinheim) 353 (2020) e1900299. https://doi.org/10.1002/ardp.201900299.

[7] P. Brandao, C. Marques, E.P.Carreiro, M. Pineiro, A.J. Burke. Engaging isatins in multicomponent reactions (MCRs) - easy access to structural diversity. The Chemical Record 21 (2021) 1-115. https://doi.org/10.1002/tcr.202000167. 
[8] Zh. Ding, M. Zhou, Ch. Zeng. Recent advances in isatin hybrids as potential anticancer agents. Archiv der Pharmazie (Weinheim) 353 (2020) e1900367. https://doi.org/10.1002/ardp.201900367.

[9] R.E.F. de Paiva, E. Guimaraes Vieira, D.R. da Silva, C.A. Wegermann, A.M. Costa Ferreira. Anticancer compounds based on isatin-derivatives: strategies to ameliorate selectivity and efficiency. Frontiers in Molecular Biosciences 7 (2021) 627272. https://doi.org/10.3389/fmolb.2020.627272.

[10] D.-J. Fu, Y.-F. Zhang, A.-Q. Chang, J. Li. $\beta$-Lactams as promising anticancer agents: Molecular hybrids, structure activity relationships and potential targets. European Journal of Medicinal Chemistry 201 (2020) 112510. https://doi.org/10.1016/i.ejmech.2020.112510.

[11] R. Kumar, P. Takkar. Repositioning of Isatin hybrids as novel anti-tubercular agents overcoming preexisting antibiotics resistance. Medicinal Chemistry Research 30 (2021) 847-876. https://doi.org/10.1007/s00044-021-02699-5.

[12] Zh. Xu, Sh. Zhang, Ch. Gao, J. Fan, F. Zhao, Z.-Sh. Lv, L.-Sh. Feng. Isatin hybrids and their antituberculosis activity, Chinese Chemical Letters 28 (2017) 159-167. https://doi.org/10.1016/j.cclet.2016.07.032.

[13] F. Song, Zh. Li, Yu. Bian, X. Huo, Ju. Fang, L. Shao, M. Zhou. Indole/isatin-containing hybrids as potential antibacterial agents. Archiv der Pharmazie 353 (2020) e2000143. https://doi.org/10.1002/ardp.202000143.

[14] Shagufta, I. Ahmad. The race to treat COVID-19: Potential therapeutic agents for the prevention and treatment of SARS-CoV-2. European Journal of Medicinal Chemistry 213 (2021) 113157. https://doi.org/10.1016/j.ejmech.2021.113157.

[15] M. Konwar, D. Sarma. Advances in developing small molecule SARS 3CLpro inhibitors as potential remedy for corona virus infection. Tetrahedron 77 (2021) 131761. https://doi.org/10.1016/j.tet.2020.131761.

[16] V.K. Pandey, A. Dwivedi, O.P. Pandey, S.K. Sengupta. Organophosphorus derivatives containing isatin3-hydrazones as chemotherapeutants against fungal pathogens of sugarcane. Journal of Agricultural and Food Chemistry 56 (2008) 10779. https://doi.org/10.1021/jf801975z.

[17] L.S. Zampirolli, M.J. de Lemos, V.T. Goncalves, M.A.A. de Souza, S.R. de Souza, V.M. Rumjanek, J.B.N. DaCosta. Synthesis, characterization, and biological activity of a new class of dialkylphosphorylhydrazone derivatives of isatin. Quimica Nova 37 (2014) 989-995. https://doi.org/10.5935/0100-4042.20140162.

[18] C. Viegas-Junior, A. Danuello, V. da Silva Bolzani, E.J. Barreiro, C.A.M. Fraga. Molecular hybridization: a useful tool in the design of new drug prototypes. Current Medicinal Chemistry 14 (2007) 1829-1852. https://doi.org/10.2174/092986707781058805.

[19] G. Berube. An overview of molecular hybrids in drug discovery. Expert Opinion on Drug Discovery 11 (2016) 281-305. https://doi.org/10.1517/17460441.2016.1135125.

[20] P.L. Bosquesi, Th.R. Ferreira Melo, E.O. Vizioli, J.L. dos Santos, M.Ch. Chung. Anti-Inflammatory drug design using a molecular hybridization approach. Pharmaceuticals 4 (2011) 1450-1474. https://doi.org/10.3390/ph4111450.

[21] R. Meleddu, S. Distinto, A. Corona, E. Tramontano, G. Bianco, C. Melis, F. Cottiglia, E. Maccioni., Isatin thiazoline hybrids as dual inhibitors of HIV-1 reverse transcriptase. Journal of Enzyme Inhibition and Medicinal Chemistry 130 (2017) 130-136. https://doi.org/10.1080/14756366.2016.1238366.

[22] M.C. Jennings, K.P.C. Minbiole, W.M. Wuest. Quaternary ammonium compounds: an antimicrobial mainstay and platform for innovation to address bacterial resistance. ACS Infection Diseases 1 (2015) 288-303. https://doi.org/10.1021/acsinfecdis.5b00047.

[23] A.N. Vereshchagin, N.A. Frolov, K.S. Egorova, M.M. Seitkalieva, V.P. Ananikov. Quaternary ammonium compounds (QACS) and ionic liquids (ILS) as biocides: from simple antiseptics to tunable antimicrobials. International. Journal of Molecular Sciences 22 (2021) 6793. https://doi.org/10.3390/ijms22136793.

[24] A.V. Bogdanov, I.F. Zaripova, A.D. Voloshina, A.S. Strobykina, N.V. Kulik, S.V. Bukharov, V.F. Mironov. Isatin derivatives containing sterically hindered phenolic fragment and water-soluble acyl hydrazones 
on their basis: synthesis and antimicrobial activity. Russian Journal of General Chemistry 88 (2018) 57-67. https://doi.org/10.1134/S1070363218010097.

[25] A.V. Bogdanov, I.F. Zaripova, A.D. Voloshina, A.S. Strobykina, N.V. Kulik, S.V. Bukharov, Ju.K. Voronina, A.R. Khamatgalimov, V.F. Mironov. Synthesis and antimicrobial activity evaluation of some novel water-soluble isatin-3-acylhydrazones. Monatshefte Chemie 149 (2018) 111-117. https://doi.org/10.1007/s00706-017-2049-y.

[26] A.V. Bogdanov, I.F. Zaripova, A.D. Voloshina, A.S. Sapunova, N.V. Kulik, S.V. Bukharov, Ju.K. Voronina, A.E. Vandyukov, V.F. Mironov. Synthesis and biological evaluation of new isatin-based QACs with high antimicrobial potency. ChemistrySelect 4 (2019) 6162-6166. https://doi.org/10.1002/slct.201901708.

[27] T.N. Pashirova, A.V. Bogdanov, I.F. Zaripova, E.A. Burilova, A.E. Vandyukov, A.S. Sapunova, I.I. Vandyukova, A.D. Voloshina, V.F. Mironov, L.Ya. Zakharova. Tunable amphiphilic $\pi$-systems based on isatin derivatives containing a quaternary ammonium moiety: The role of alkyl chain length in biological activity. Journal of Molecular Liquids 290 (2019) 111220. https://doi.org/10.1016/j.molliq.2019.111220.

[28] A.V. Bogdanov, M.E. Kadomtseva, S.V. Bukharov, A.D. Voloshina, V.F. Mironov. Effect of the cationic moiety on the antimicrobial activity of sterically hindered isatin 3-hydrazone derivatives. Russian Journal of Organic Chemistry 56 (2020) 555-558. https://doi.org/10.1134/S107042802003032X.

[29] A.V. Bogdanov, O.V. Andreeva, M.G. Belenok, A.D. Voloshina, K.I.Enikeeva, A.V.Samorodov, V.F. Mironov. Synthesis of triazolylisatins glycoconjugates and some ammonium hydrazones on their basis. Russian Journal of General Chemistry 91 (2021) 1282-1291. https://doi.org/10.1134/$\underline{\mathrm{S} 1070363221070045}$.

[30] A.V. Bogdanov, A.D. Voloshina, A.R. Khamatgalimov, N.V. Terekhova, V.F. Mironov. On the effect of the nature of substituents on the antimicrobial activity of water-soluble acylhydrazones on the isatin scaffold. Doklady Chemistry 494 (2020) 136-140. https://doi.org/10.1134/S0012500820090013.

[31] A.D. Voloshina, S.K. Gumerova, A.S. Sapunova, N.V. Kulik, A.B. Mirgorodskaya, A.A. Kotenko, T.M. Prokopyeva, V.A. Mikhailov, L.Ya. Zakharova, O.G. Sinyashin. The structure-activity correlation in the family of dicationic imidazolium surfactants: antimicrobial properties and cytotoxic effect. Biochimica et Biophysica Acta (BBA)-General Subjects 1864 (2020) 129728. https://doi.org/10.1016/j.bbagen.2020.129728.

[32] A.D. Voloshina, A.S. Sapunova, N.V. Kulik, M.G. Belenok, I.Yu. Strobykina, A.P. Lyubina, S.K. Gumerova, V.E. Kataev. Antimicrobial and cytotoxic effects of ammonium derivatives of diterpenoids steviol and isosteviol. Bioorganic and Medicinal Chemistry 32 (2021) 115974. https://doi.org/10.1016/i.bmc.2020.115974.

[33] G. Born. Aggregation of blood platelets by adenosine diphosphate and its reversal. Nature 194 (1962) 927-929. https://doi.org/10.1038/194927b0.

[34] C. Pane, M. Caputo, G. Francese, G. Manganiello, R. Lo Scalzo, G. Mennella, M. Zaccardelli. Managing Rhizoctonia damping-off of rocket (Eruca sativa) seedlings by drench application of bioactive potato leaf phytochemical extracts. Biology 9 (2020) 270. https://doi.org/10.3390/biology9090270.

[35] A. Moreno-Gavira, F. Dianez, B. Sanchez-Montesinos, M. Santos. Biocontrol effects of Paecilomyces variotii against fungal plant diseases. Journal of Fungi 7 (2021) 415. https://doi.org/10.3390/jof7060415.

[36] M. Greener, Drug safety on trial. EMBO reports 6 (2005) 202-204. https://doi.org/10.1038/sj.embor.7400353.

[37] A.E. Schultze, D.B. Walker, J.R. Turk, J.M. Tarrant, M.B. Brooks, S.D. Pettit. Current practices in preclinical drug development: gaps in hemostasis testing to assess risk of thromboembolic injury. Toxicologic Pathology 41 (2013) 445-453. https://doi.org/10.1177/0192623312460924.

[38] H. Abd-El-Khair, T.G. Abdel-Gaied, M.S. Mikhail, A.I. Abdel-Alim, H.I S. El-Nasr. Biological control of Pectobacterium carotovorum subsp. carotovorum, the causal agent of bacterial soft rot in vegetables, in vitro and in vivo tests. Bulletin of the National Research Centre 45 (2021) 37. https://doi.org/10.1186/s42269-021-00491-4. 
[39] X. Huang, J. Ren, P. Li, S. Feng, P. Dong, M. Ren. Potential of microbial endophytes to enhance the resistance to postharvest diseases of fruit and vegetables. Journal of the Science of Food and Agriculture 101 (2021) 1744-1757. https://doi.org/10.1002/jsfa.10829.

[40] L. Ragasova, E. Penazova, F. Gazdik, J. Pecenka, J. Cechova, R. Pokluda, M. Baranek, D. Grzebelus, A. Eichmeier. The change of bacterial spectrum after storage of $X$. campestris pv. campestris inoculated cabbage heads (Brassica oleracea var. capitata L.). Agronomy $10 \quad$ (2020) 443. https://doi.org/10.3390/agronomy10030443.

[41] M. Ray, A. Ray, S. Dash, A. Mishra, K.G. Achary, S. Nayak, S. Singh. Fungal disease detection in plants: Traditional assays, novel diagnostic techniques and biosensors. Biosensors and Bioelectronics 87 (2017) 708-723. https://doi.org/10.1016/j.bios.2016.09.032.

[42] T. Wang, C. Gao, Y. Cheng, Z. Li, J. Chen, L. Guo, J. Xu. Molecular diagnostics and detection of oomycetes on fiber crops. Plants 9 (2020) 769. https://doi.org/10.3390/plants9060769.

[43] K. Mastanjevic, V. Krstanovic, K. Mastanjevic, B. Sarkanj. Malting and brewing industries encounter Fusarium spp. related problems. Fermentation 4 (2018) 3. https://doi.org/10.3390/fermentation$\underline{4010003}$.

[44] J.-H. Han, G.-C. Park, K.S. Kim. Antagonistic evaluation of Chromobacterium sp. JH7 for biological control of ginseng root rot caused by Cylindrocarpon destructans. Mycobiology 45 (2017) 370-378. https://doi.org/10.5941/MYCO.2017.45.4.370.

[45] E.M. Chudinova, V.A. Platonov, A.V. Alexandrova, S.N. Elansky. Biology and resistance of phytopathogenic fungus Ilyonectria crassa to fungicides. Plant Protection News 103 (2020) 192-196. https://doi.org/10.31993/2308-6459-2020-103-3-13431.

(C)2022 by the authors; licensee IAPC, Zagreb, Croatia. This article is an open-access article distributed under the terms and conditions of the Creative Commons Attribution license (http://creativecommons.org/licenses/by/3.0/) (cc)) BY 